\title{
Pollen Geochronology from the Atlantic Coast of the United States during the Last 500 Years
}

\author{
Margaret A. Christie ${ }^{1,2, *} \mathbb{C}^{\text {, Christopher E. Bernhardt }}{ }^{3}$, Andrew C. Parnell ${ }^{4}$, Timothy A. Shaw ${ }^{5} \mathbb{D}^{1}$, \\ Nicole S. Khan ${ }^{6}$, D. Reide Corbett ${ }^{7}\left(\mathbb{D}\right.$, Ane García-Artola ${ }^{8}$, Jennifer Clear ${ }^{9}$, Jennifer S. Walker ${ }^{10}($, \\ Jeffrey P. Donnelly ${ }^{11}$, Tobias R. Hasse ${ }^{12}$ and Benjamin P. Horton ${ }^{5,13}$
}

check for updates

Citation: Christie, M.A.; Bernhardt, C.E.; Parnell, A.C.; Shaw, T.A.; Khan, N.S.; Corbett, D.R.; García-Artola, A.; Clear, J.; Walker, J.S.; Donnelly, J.P.; et al. Pollen Geochronology from the Atlantic Coast of the United States during the Last 500 Years. Water 2021 13, 362. https://doi.org/ 10.3390/w13030362

Academic Editors: Marcel J. F. Stive and Monica Bini

Received: 22 December 2020

Accepted: 27 January 2021

Published: 31 January 2021

Publisher's Note: MDPI stays neutral with regard to jurisdictional claims in published maps and institutional affiliations.

Copyright: (C) 2021 by the authors Licensee MDPI, Basel, Switzerland. This article is an open access article distributed under the terms and conditions of the Creative Commons Attribution (CC BY) license (https:// creativecommons.org/licenses/by/ $4.0 /)$.
1 Department of Environmental Studies, McDaniel College, 2 College Hill, Westminster, MD 21157, USA Department of Marine and Coastal Sciences, Rutgers University, New Brunswick, NJ 08854, USA Florence Bascom Geoscience Center, U.S. Geological Survey, Reston, VA 20192, USA; cbernhardt@usgs.gov

4 Hamilton Institute, Insight Centre for Data Analytics, Maynooth University, W23 F2K8 Kildare, Ireland; Andrew.Parnell@mu.ie

5 Earth Observatory of Singapore, Nanyang Technological University, Singapore 639798, Singapore; tshaw@ntu.edu.sg (T.A.S.); BPHorton@ntu.edu.sg (B.P.H.)

6 Department of Earth Sciences and the Swire Institute of Marine Science, The University of Hong Kong, Hong Kong, Hong Kong SAR; nskhan@hku.hk

7 Department of Coastal Studies, East Carolina University, Wanchese, NC 27981, USA; CORBETTD@ecu.edu

8 Departamento de Geología, Universidad del País Vasco UPV/EHU, 48080 Bilbao, Spain; ane.garcia@ehu.eus

9 Department of Geography and Environmental Science, Liverpool Hope University, Liverpool 13088, UK; clearj@hope.ac.uk

10 Department of Earth and Planetary Sciences, Rutgers University, Piscataway, NJ 08854, USA; walker@marine.rutgers.edu

11 Woods Hole Oceanographic Institution, Woods Hole, MA 02543, USA; jdonnelly@whoi.edu

12 Department of Earth Sciences, University of Delaware, Newark, DE 19716, USA; tobiack@udel.edu

13 Singapore and Asian School of the Environment, Nanyang Technological University, Singapore 639798, Singapore

* Correspondence: mchristie@mcdaniel.edu; Tel.: +1-410-857-2400

Abstract: Building robust age-depth models to understand climatic and geologic histories from coastal sedimentary archives often requires composite chronologies consisting of multi-proxy age markers. Pollen chronohorizons derived from a known change in vegetation are important for agedepth models, especially those with other sparse or imprecise age markers. However, the accuracy of pollen chronohorizons compared to other age markers and the impact of pollen chronohorizons on the precision of age-depth models, particularly in salt marsh environments, is poorly understood. Here, we combine new and published pollen data from eight coastal wetlands (salt marshes and mangroves) along the Atlantic Coast of the United States (U.S.) from Florida to Connecticut to define the age and uncertainty of 17 pollen chronohorizons. We found that 13 out of 17 pollen chronohorizons were consistent when compared to other age markers (radiocarbon, radionuclide ${ }^{137} \mathrm{Cs}$ and pollution markers). Inconsistencies were likely related to the hyperlocality of pollen chronohorizons, mixing of salt marsh sediment, reworking of pollen from nearby tidal flats, misidentification of pollen signals, and inaccuracies in or misinterpretation of other age markers. Additionally, in a total of 24 models, including one or more pollen chronohorizons, increased precision (up to 41 years) or no change was found in 18 models.

Keywords: pollen; age-depth models; geochronology; Holocene; coastal wetlands

\section{Introduction}

The last millennium contains major environmental changes that are important for understanding how the Earth may respond to future perturbations [1-3]. Environmental changes include natural climatic changes from the Medieval Climate Anomaly to the Little 
Ice Age (LIA) $[4,5]$ and the onset of modern anthropogenically-driven climate and land use changes $[6,7]$.

A robust, highly resolved geochronology in sedimentary archives is critical to constrain the timing of major environmental changes during the last millennium [8]. Every significant advance in geochronology has produced a paradigm-shifting breakthrough in our understanding of environmental changes from proxy records [9]. The geochronology of proxy records of environmental change from $\sim 50 \mathrm{ka}$ to present is commonly constrained using radiocarbon dating [10-12]. However, radiocarbon results dating to the last few centuries often yield age estimates with multiple distinct ranges due to the highly variable relative concentration of radiocarbon in the atmosphere. For example, variations in the atmospheric ${ }^{14} \mathrm{C} /{ }^{12} \mathrm{C}$ ratio from changes in solar activity (e.g., minima in 1500 , 1700 , and $1815 \mathrm{CE}$ ) [13] and combustion of radiocarbon-free fossil fuels primarily since the 1960s (known as the Suess effect) [14-16], cause some samples to have multiple potential age-ranges $[17,18]$. The last few hundred years of sediment-based proxy records can also be dated using a composite chronology including short-lived radioisotopes, such as ${ }^{210} \mathrm{~Pb}$ [19-22] and ${ }^{137} \mathrm{Cs}$ [23,24], and anthropogenic pollution markers [25-27] (Figure 1). However, there are limitations imposed by sedimentary processes, sampling, and analytical factors of ${ }^{210} \mathrm{~Pb}$, which can generate erroneous ages [28,29]. Pollution markers of trace metals are available after the regional onset of industrial activity [30-32] but are absent or unknown in many regions [33-35].

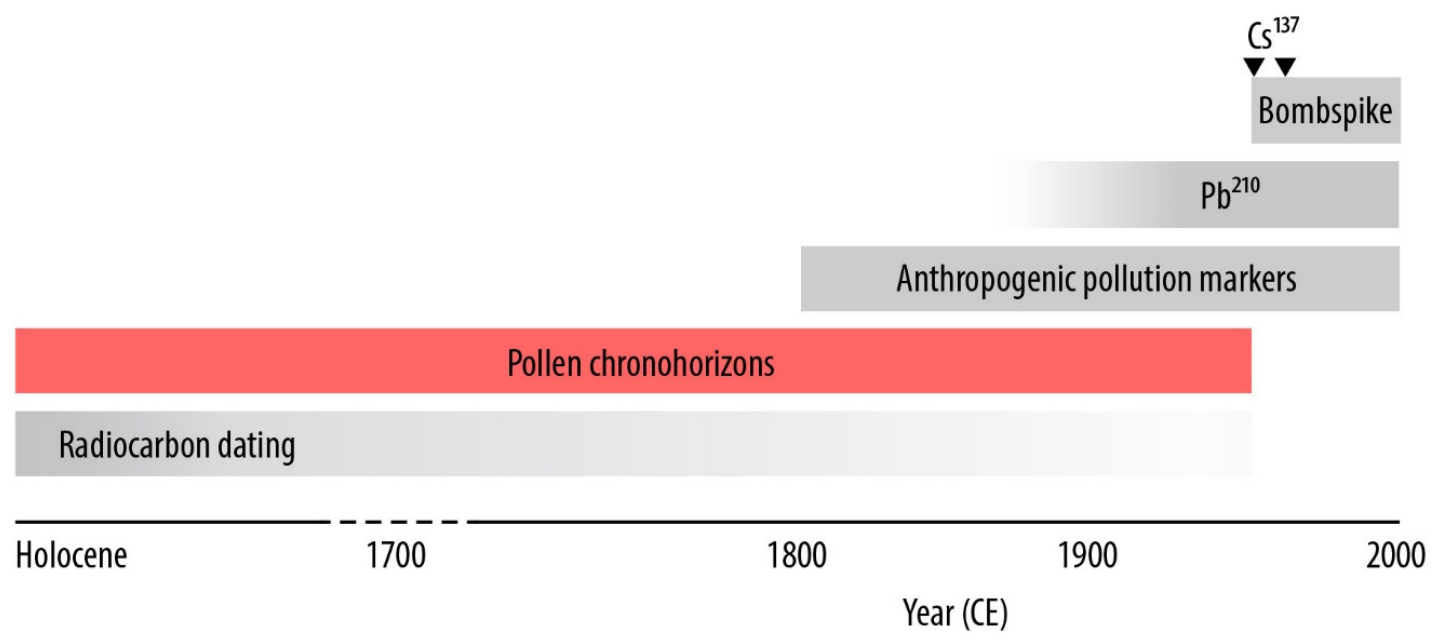

Figure 1. Conceptual diagram of dating techniques and their age ranges highlighting the potential chronological gap between radiocarbon dating and pollution markers that pollen chronohorizons may circumvent.

The radiocarbon calibration plateaus and oscillations that occur between 1500 and $1950 \mathrm{CE}$ and the limitations of short-lived radioisotopes and pollution markers make dating phenomena like the LIA and the onset of anthropogenically-driven climate change uncertain [17]. Pollen evidence of land-use changes that occurred during European settlement along the U.S. Atlantic Coast [36,37] provides chronohorizons that can improve the precision of age-depth models by filling this age-uncertainty gap [38-40]. Because fossil pollen is readily preserved in coastal, lacustrine, and salt and freshwater marsh sediments, pollen chronohorizons are applied in a variety of paleoclimate [41], relative sea level [42], and storm [43] reconstructions. Pollen chronohorizons are derived from changes in the relative abundance of pollen of certain plant taxa [36,44,45]. For example, a deforestation chronohorizon can be estimated from a decrease in arboreal pollen and a simultaneous increase in ragweed (Ambrosia) [36]. The ages of chronohorizons are estimated from personal journals, letters, and almanacs that contain information about specific changes in vegetation $[25,26,40]$. However, many of the ages associated with the chronohorizons have unknown uncertainties due to variations in the transport and preservation of pollen in the sedimentary record [46]. Additionally, applying chronohorizons to broad regions may 
be hampered by hyperlocality, that is, vegetation changes that are restricted to a specific location by dispersal mechanisms [47].

Here, we have collected published and unpublished pollen and chronology data (e.g., radiocarbon, ${ }^{137} \mathrm{Cs}$ and pollution horizons) from sediment cores collected from eight coastal wetlands (salt marshes and mangroves) along the U.S. Atlantic Coast. Coastal wetlands are ecologically and economically important environments [48], which are under threat from sea-level rise, storm surges, and eutrophication [49-52]. We investigated the applicability of pollen chronohorizons from salt marsh and mangrove environments that have been studied using a consistent methodology for dating, sediment sampling, and analysis $[27,42,53]$. We documented eight unique pollen chronohorizons with up to three chronohorizons per study site (17 chronohorizons in total). We compared pollen chronohorizons to other age markers (radiocarbon, ${ }^{137} \mathrm{Cs}$, and pollution markers) to examine their consistency with other markers and their influence on the precision of age-depth models. We applied a Bayesian age-depth framework (Bchron) [54], which illustrated that 13 out of 17 ages assigned to individual pollen chronohorizons were consistent when compared with dates derived using other age markers. Inconsistencies are likely due to hyperlocality, sediment mixing, misinterpretation of pollen signals, and/or incorrect pollution and radiocarbon dates. We show that the greatest influence on the precision of age models occurred at coastal wetland sites with limited chronological data, highlighting the importance of pollen chronohorizons and providing a better understanding of age-depth modeling in these critical coastal environments.

\section{Study Sites}

We compiled pollen and chronological data from eight coastal wetlands (Figure 2a, Table 1). We include four published records (New York, New Jersey, North Carolina, and northern Florida) (Appendix A) and four newly analyzed records with unpublished chronological data (Connecticut, Delaware, Maryland, and southern Florida) (Table 2). Full site descriptions of the published and unpublished records can be found in the original publications and Appendix B, respectively.
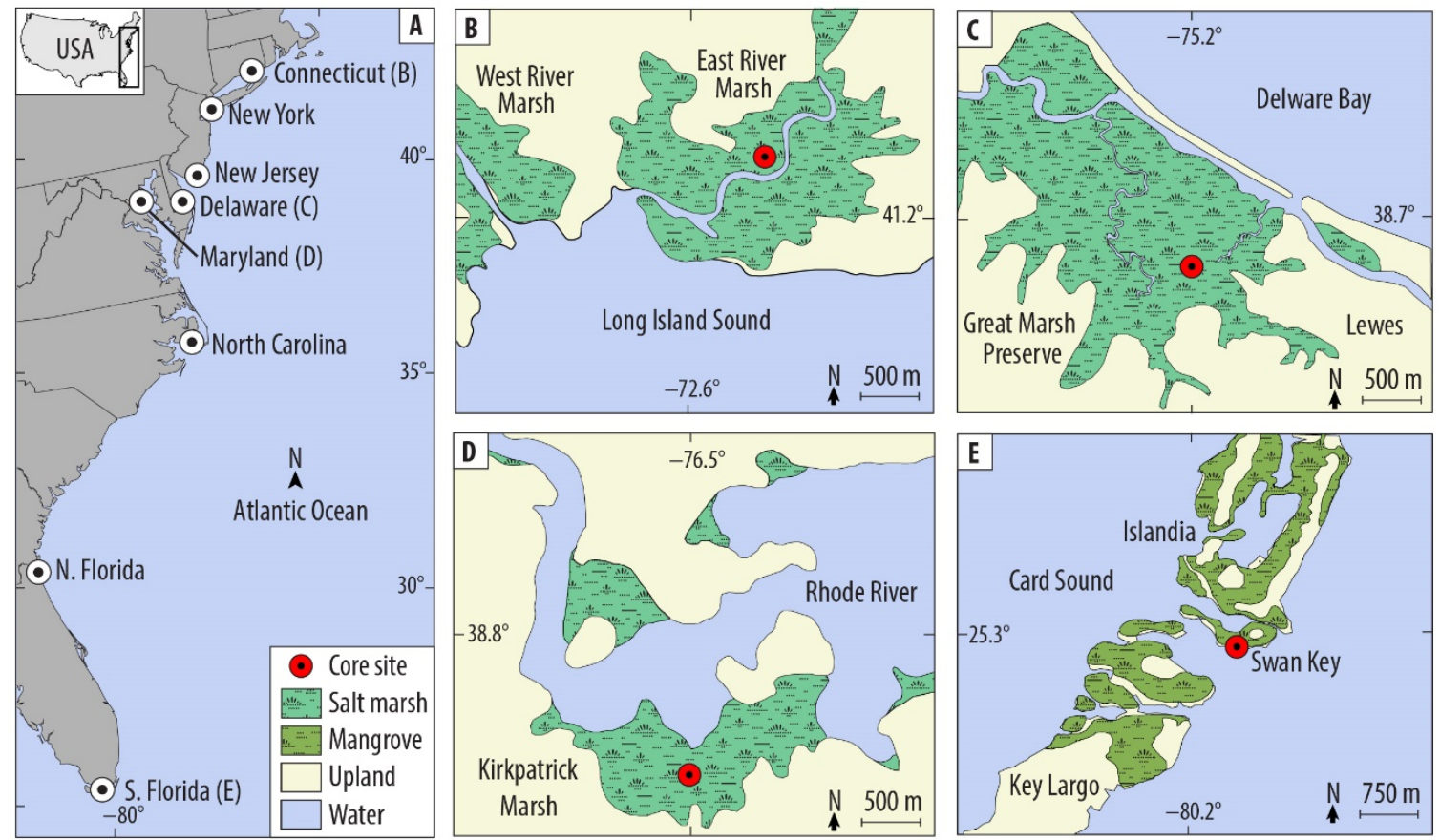

Figure 2. Map of U.S. Atlantic Coast (A) showing the relative location of eight published and unpublished study sites, as well as individual site maps for Connecticut (B), Delaware (C), Maryland (D), and Southern Florida (E). Maps of other sites can be found in the original publications. 
Table 1. Site Descriptions. Regional vegetation identified using [55]. The site description and chronology related to other age markers can be found in the original publication.

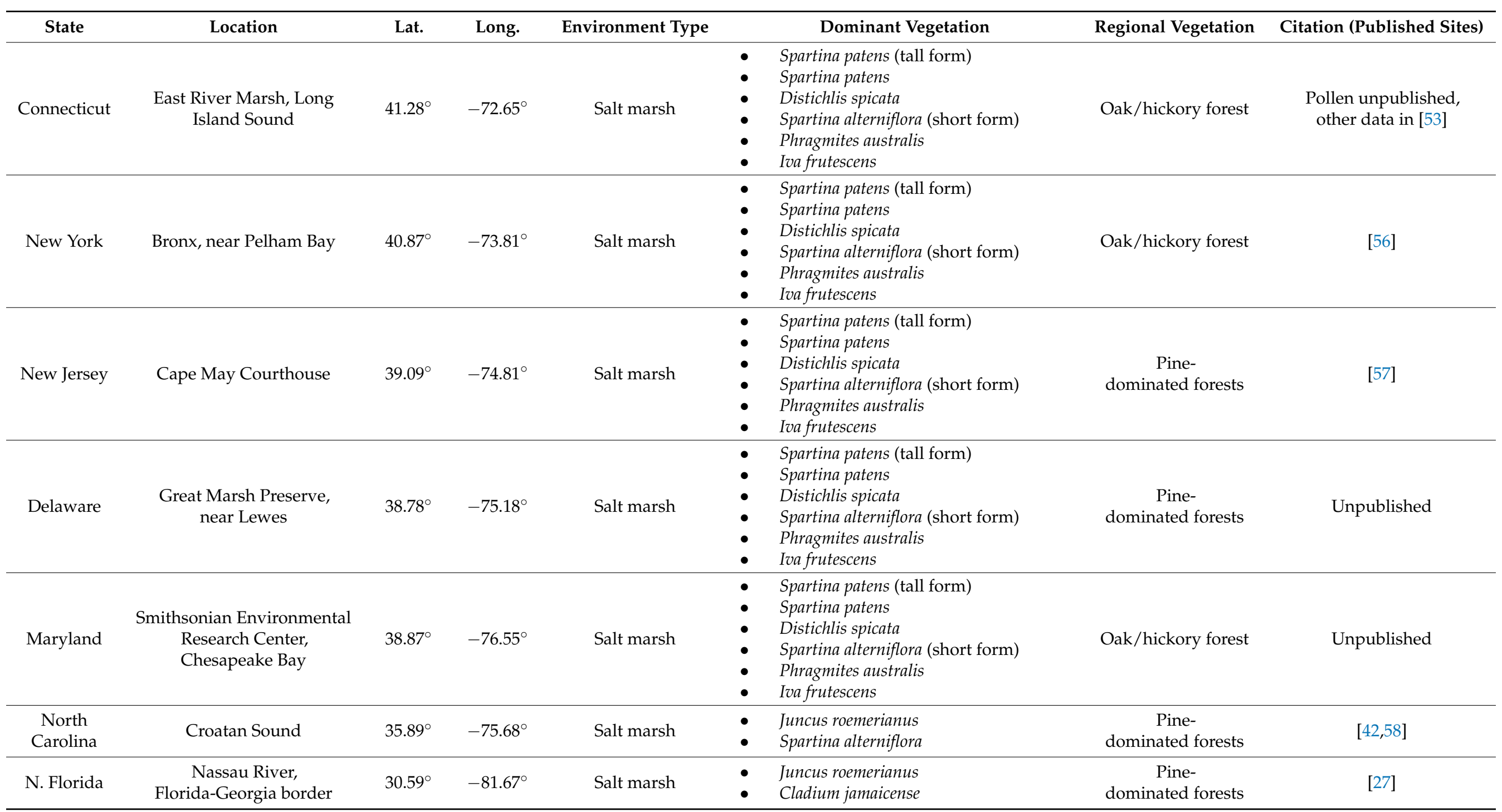


Table 1. Cont.

\begin{tabular}{|c|c|c|c|c|c|c|c|}
\hline State & Location & Lat. & Long. & Environment Type & Dominant Vegetation & Regional Vegetation & Citation (Published Sites) \\
\hline S. Florida & Swan Key & $25.34^{\circ}$ & $-80.25^{\circ}$ & Mangrove swamp & $\begin{array}{ll}\text { - } & \text { Rhizophora mangle } \\
\text { - } & \text { Avicennia germinans } \\
\text { - } & \text { Laguncularia racemosa }\end{array}$ & $\begin{array}{l}\text { Tropical hardwood, } \\
\text { Dade pine }\end{array}$ & Unpublished \\
\hline
\end{tabular}

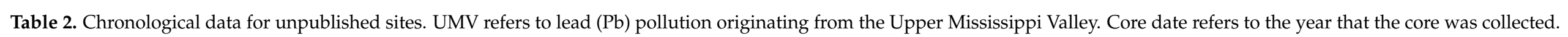

Years before present is abbreviated as YBP with "present" defined at 1950.

\begin{tabular}{|c|c|c|c|c|c|c|c|c|c|c|c|c|}
\hline & \multicolumn{4}{|c|}{ Delaware } & \multicolumn{4}{|c|}{ Maryland } & \multicolumn{4}{|c|}{ Southern Florida } \\
\hline & Lab Code & Depth (cm) & $\begin{array}{c}\text { Age }\left({ }^{14} \mathrm{C}\right. \\
\text { Years) }\end{array}$ & $\begin{array}{c}\text { Calibrated Age } \\
\text { Range (YBP) }\end{array}$ & Lab Code & Depth (cm) & $\begin{array}{c}\text { Age }\left({ }^{14} \mathrm{C}\right. \\
\text { Years) }\end{array}$ & $\begin{array}{c}\text { Calibrated Age } \\
\text { Range (YBP) }\end{array}$ & Lab Code & Depth (cm) & $\begin{array}{c}\text { Age }\left({ }^{14} \mathrm{C}\right. \\
\text { Years) }\end{array}$ & $\begin{array}{c}\text { Calibrated Age } \\
\text { Range (YBP) }\end{array}$ \\
\hline \multirow{23}{*}{ 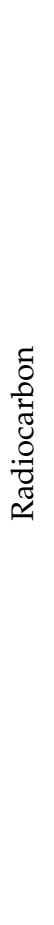 } & OS-132389 & $67 \pm 4$ & $260 \pm 15$ & $287-313$ & OS-115941 & $62 \pm 2$ & $95 \pm 20$ & $33-255$ & OS-134377 & $33.5 \pm 1$ & $105 \pm 20$ & $29-258$ \\
\hline & OS-132390 & $83 \pm 4$ & $205 \pm 20$ & $1-294$ & OS-114600 & $78 \pm 2$ & $385 \pm 15$ & $339-497$ & OS-132811 & $50.5 \pm 1$ & $350 \pm 15$ & $324-473$ \\
\hline & OS-124588 & $98 \pm 4$ & $335 \pm 15$ & $319-457$ & OS-115940 & $92 \pm 2$ & $240 \pm 15$ & $156-303$ & OS-132812 & $77.5 \pm 1$ & $1030 \pm 20$ & $927-963$ \\
\hline & OS-121533 & $113 \pm 4$ & $190 \pm 20$ & $1-285$ & OS-130621 & $97 \pm 2$ & $405 \pm 15$ & $463-503$ & OS-134336 & $91.5 \pm 1$ & $1140 \pm 15$ & 987-1066 \\
\hline & OS-130673 & $114 \pm 4$ & $315 \pm 15$ & $311-434$ & OS-115939 & $110 \pm 2$ & $405 \pm 15$ & $464-503$ & OS-132813 & $98.5 \pm 1$ & $1110 \pm 15$ & $972-1053$ \\
\hline & OS-124587 & $126 \pm 4$ & $435 \pm 15$ & $493-512$ & OS-130554 & $117 \pm 2$ & $665 \pm 15$ & $568-665$ & OS-132814 & $107.5 \pm 1$ & $1530 \pm 25$ & $1361-1515$ \\
\hline & OS-123152 & $133 \pm 4$ & $590 \pm 20$ & $546-641$ & OS-114599 & $133 \pm 2$ & $850 \pm 20$ & $712-787$ & OS-134379 & $126.5 \pm 1$ & $1720 \pm 20$ & $1569-1693$ \\
\hline & OS-121534 & $139 \pm 4$ & $710 \pm 20$ & $656-681$ & OS-115938 & $154 \pm 2$ & $980 \pm 20$ & 805-931 & OS-129823 & $145.5 \pm 1$ & $1800 \pm 15$ & $1647-1803$ \\
\hline & OS-123153 & $149 \pm 4$ & $945 \pm 20$ & 799-919 & OS-114598 & $175 \pm 2$ & $1120 \pm 20$ & 974-1059 & OS-134337 & $159.5 \pm 1$ & $1700 \pm 15$ & 1563-1682 \\
\hline & OS-124589 & $155 \pm 4$ & $905 \pm 20$ & 765-903 & OS-115937 & $194 \pm 2$ & $1170 \pm 25$ & 1005-1172 & OS-133069 & $178.5 \pm 1$ & $2150 \pm 20$ & 2071-2292 \\
\hline & OS-132391 & $159 \pm 4$ & $1030 \pm 15$ & $929-960$ & OS-114597 & $206 \pm 2$ & $1220 \pm 20$ & $1076-1229$ & OS-134690 & $191.5 \pm 1$ & $2330 \pm 20$ & $2333-2354$ \\
\hline & OS-121535 & $162 \pm 4$ & $1270 \pm 25$ & $1178-1272$ & OS-115936 & $225 \pm 2$ & $1290 \pm 20$ & $1185-1278$ & OS-133066 & $211.5 \pm 1$ & $2160 \pm 15$ & 2124-2294 \\
\hline & OS-130880 & $164 \pm 4$ & $1230 \pm 20$ & $1018-1249$ & OS-114596 & $247 \pm 2$ & $1460 \pm 25$ & 1309-1389 & OS-134574 & $236.5 \pm 1$ & $2350 \pm 25$ & $2338-2436$ \\
\hline & OS-132392 & $170 \pm 4$ & $1240 \pm 15$ & 1110-1251 & OS-115935 & $265 \pm 2$ & $1650 \pm 20$ & 1529-1597 & OS-129771 & $250.5 \pm 1$ & $2500 \pm 20$ & 2499-2715 \\
\hline & OS-130881 & $176 \pm 4$ & $1190 \pm 20$ & $1065-1174$ & OS-115934 & $286 \pm 2$ & $1800 \pm 20$ & 1639-1809 & OS-134380 & $261.5 \pm 1$ & $2580 \pm 30$ & $2546-2753$ \\
\hline & OS-130679 & $181 \pm 4$ & $1500 \pm 15$ & $1352-1403$ & OS-114595 & $302 \pm 2$ & $1740 \pm 20$ & 1585-1702 & OS-132815 & $278.5 \pm 1$ & $2790 \pm 20$ & 2850-2944 \\
\hline & OS-130798 & $203 \pm 4$ & $1770 \pm 15$ & $1627-1713$ & OS-114593 & $348 \pm 2$ & $2050 \pm 25$ & 1947-2100 & OS-132816 & $318.5 \pm 1$ & $2970 \pm 20$ & $3077-3203$ \\
\hline & OS-132393 & $205 \pm 4$ & $1600 \pm 15$ & 1420-1535 & OS-130622 & $362 \pm 2$ & $2100 \pm 15$ & 2010-2118 & OS-134692 & $330.5 \pm 1$ & $3180 \pm 25$ & $3367-3447$ \\
\hline & OS-130697 & $213 \pm 4$ & $1670 \pm 20$ & 1538-1610 & OS-124303 & $382 \pm 2$ & $2660 \pm 25$ & 2749-2828 & OS-129824 & $349.5 \pm 1$ & $3550 \pm 20$ & 3739-3889 \\
\hline & OS-121537 & $219 \pm 4$ & $1660 \pm 20$ & 1534-1605 & OS-130623 & $391 \pm 2$ & $2210 \pm 20$ & 2157-2306 & OS-134338 & $361.5 \pm 1$ & $3470 \pm 20$ & $3655-3822$ \\
\hline & OS-130698 & $228 \pm 4$ & $1730 \pm 15$ & 1579-1693 & OS-124302 & $410 \pm 2$ & $2180 \pm 20$ & 2135-2300 & OS-134381 & $394.5 \pm 1$ & $3600 \pm 30$ & $3843-3975$ \\
\hline & OS-130699 & $238 \pm 4$ & $1860 \pm 15$ & $1737-1858$ & OS-130555 & $420 \pm 2$ & $2360 \pm 20$ & $2345-2429$ & OS-133068 & $415.5 \pm 1$ & $3870 \pm 20$ & $4237-4402$ \\
\hline & OS-132394 & $244 \pm 4$ & $1880 \pm 20$ & 1747-1871 & OS-130624 & $436 \pm 2$ & $2420 \pm 15$ & $2364-2644$ & OS-134575 & $439.5 \pm 1$ & $3830 \pm 20$ & 4158-4303 \\
\hline
\end{tabular}


Table 2. Cont.

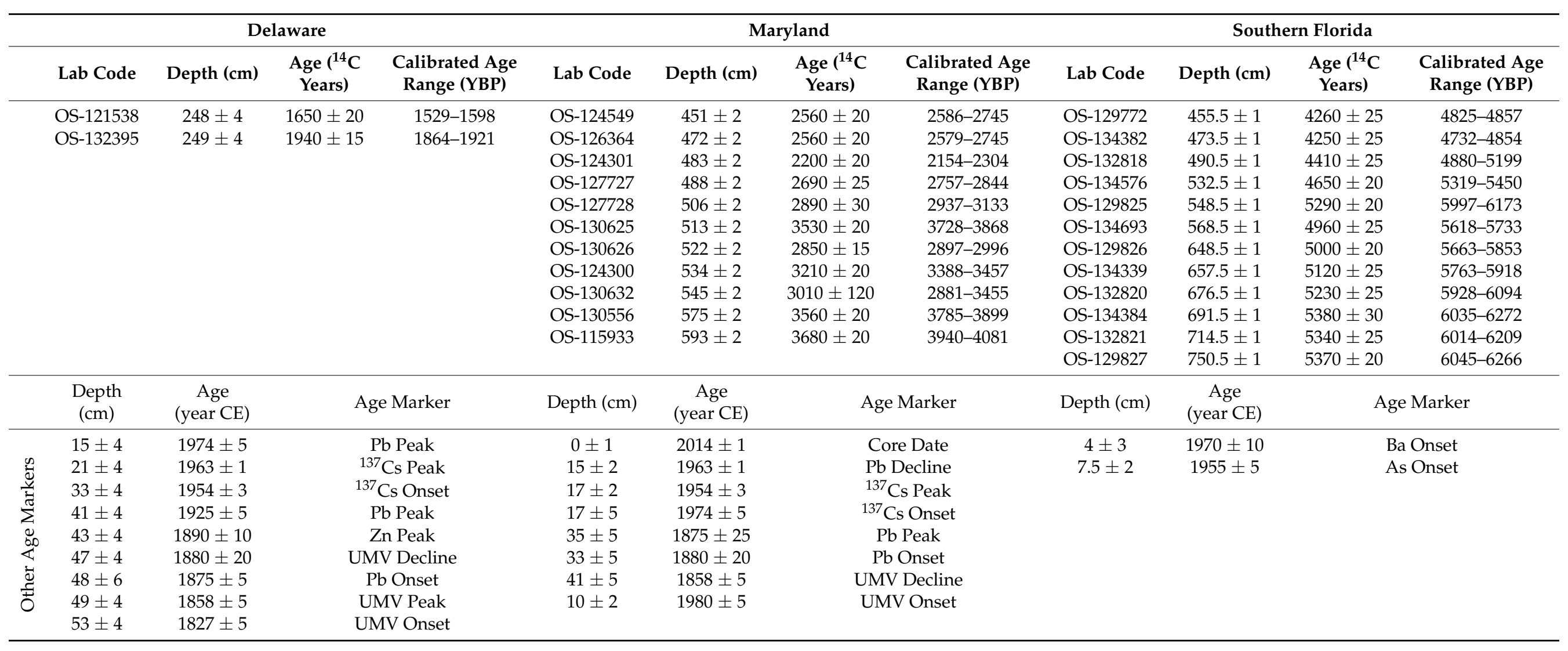


Köppen climate zones for the sites span from humid continental to tropical savanna [59]. The tidal range of the study sites varies from $0.18 \mathrm{~m}$ in New Jersey [57] to $2.44 \mathrm{~m}$ in New York [56]. Sites have been influenced by anthropogenic activities, which have altered the plant communities and, therefore, the pollen assemblages. For example, ditching was common in many of our sites to drain the marsh [60-63]. Deforestation for agriculture and wood supply varied in time but was common to all of our sites $[26,44,64]$ and is commonly used as a pollen chronohorizon [36]. Agricultural activities and importation of exotic plants such as the introduction of Casuarina in Florida [65,66], can also be recorded in pollen records.

\section{Materials and Methods}

\subsection{Sediment Sampling}

We selected sediment cores or trenches for extraction following detailed stratigraphic surveys of the underlying stratigraphy at each site. We recovered each core in overlapping, 50-cm long sections using an Eijelkamp Russian-type peat sampler [67]. In Connecticut, sediment samples were recovered from an excavated trench [53]. All cores and trench samples were placed in rigid plastic sleeves, wrapped in plastic film, and kept refrigerated until processing in the laboratory to minimize desiccation and/or decay. One core/trench section from each site was selected for detailed analysis that was representative of the site stratigraphy and was deemed most likely to produce a near-continuous reconstruction of vegetation change over the last 500 years. Site stratigraphy consisted of continuous salt marsh peat or mangrove peat throughout the studied sections.

\subsection{Chronology}

\subsubsection{Pollen Processing and Analysis}

The processing procedure for published studies can be found in the original publications. The unpublished studies followed a similar procedure. In Connecticut, Delaware, Maryland, and southern Florida, pollen sampling was performed at $4 \mathrm{~cm}$ intervals. Extraction of pollen and preparation of slides followed the methods outlined in Faegri and Iversen [68] and Bernhardt and Willard [40]. Between 100 and 500 hundred grains were counted.

We found eight unique pollen chronohorizons based on review of proposed reference dates in the literature, with up to three chronohorizons observed in each study site, producing a total of 17 chronohorizons (Figure 3). Table 3 includes detailed information regarding pollen changes and estimations of their age and associated uncertainty. We subsequently produced 24 age-depth models for the eight study sites: 17 site-specific models using individual pollen chronohorizons combined with other types of age markers and seven site-specific models with multiple pollen chronohorizons combined with other types of age markers.

The eight unique pollen chronohorizons and their criteria for identification varies among the study sites. Pollen chronohorizons vary in whether they are qualitative (i.e., based on increases or decreases in abundance) or semi-quantitative (i.e., a numerical change or presence/absence) and whether the signal is local or regional. Uncertainty ranges of pollen chronohorizons are qualitative because they are estimates of the time-lag for vegetation changes to be recorded in the sedimentary record. The eight pollen chronohorizons can be grouped into three types: land clearance; reforestation; and introduction and loss of taxa (Table 3). 


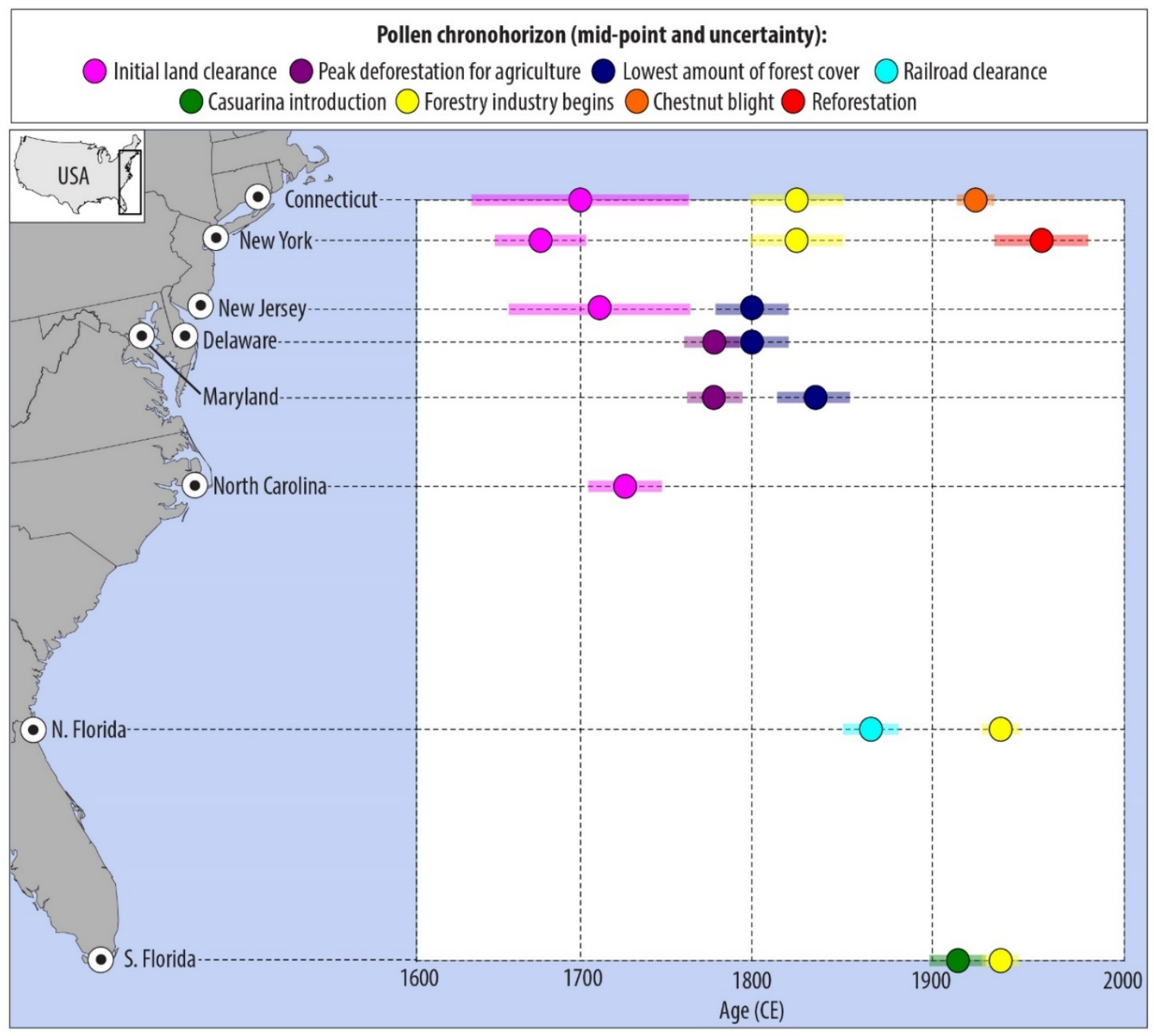

Figure 3. Timing of pollen chronohorizons documented in the literature at each study site. Pollen data from published sites are available in the original publications. 


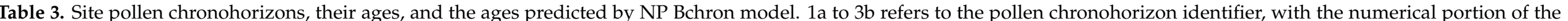

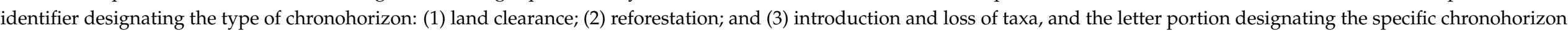
(e.g., Chestnut blight). (Figure 4, Appendix C).

\begin{tabular}{|c|c|c|c|c|c|c|}
\hline Site & $\begin{array}{c}\text { Pollen } \\
\text { Chronohorizon }\end{array}$ & $\begin{array}{c}\text { Pollen Chronohorizon } \\
\text { Age (CE) }\end{array}$ & Indicator & $\begin{array}{l}\text { Explanation of Chronohorizons Age and } \\
\text { Error, and Chosen Range for Date Analysis }\end{array}$ & $\begin{array}{l}\text { Depth, Range (cm) } \\
\text { Bchron Age (CE) }\end{array}$ & $\begin{array}{c}\text { Agreement between Pollen } \\
\text { Chronohorizons and } \\
\text { Bchron Predicted Age? }\end{array}$ \\
\hline Connecticut & $\begin{array}{l}\text { Land clearance: } \\
\text { Initial (1a) } \\
{[44,69]}\end{array}$ & $1700 \pm 60$ & $\begin{array}{l}\text { Decrease in arboreal } \\
\text { pollen, increase in } \\
\text { Ambrosia }\end{array}$ & $\begin{array}{l}\text { European settlement began in } 1640 \text { in } \\
\text { southeastern Connecticut [44] and regional } \\
\text { settlement and light agriculture occurred } \\
\text { from } 1650-1740 \text {, with extensive agriculture } \\
\text { starting in } 1750 \text { [69]. The entire age/depth } \\
\text { range between the pollen sample above and } \\
\text { below was analyzed to determine consistency } \\
\text { as relevant pollen abundance changes } \\
\text { occurred on both sides of the depth assigned } \\
\text { to this chronohorizon. }\end{array}$ & $\begin{array}{l}62 \mathrm{~cm}, 58-66 \mathrm{~cm} \\
1515-1670\end{array}$ & Yes \\
\hline Connecticut & $\begin{array}{l}\text { Land clearance: } \\
\text { Beginning of } \\
\text { the forestry } \\
\text { industry (1d) } \\
{[45,70]}\end{array}$ & $1825 \pm 25$ & $\begin{array}{l}\text { Strong decrease of } \\
\text { arboreal pollen }\end{array}$ & $\begin{array}{l}1800 \text { is the start of the cordwood industry in } \\
\text { Long Island [45]. It is suggested that the } \\
\text { forestry industry in this region was active } \\
\text { starting in } 1800 \text { until } 1850 \text { [70]. The entire } \\
\text { age/depth range between the pollen sample } \\
\text { above and below was analyzed to determine } \\
\text { consistency as relevant pollen abundance } \\
\text { changes occurred on both sides of the depth } \\
\text { assigned to this chronohorizon. }\end{array}$ & $\begin{array}{c}46 \mathrm{~cm}, 42-50 \mathrm{~cm} \\
1730-1840\end{array}$ & Yes \\
\hline Connecticut & $\begin{array}{c}\text { Introduction and } \\
\text { loss of taxa: } \\
\text { Chestnut blight (3a) } \\
{[44,45]}\end{array}$ & $1920 \pm 10$ & $\begin{array}{l}\text { Disappearance of } \\
\text { Castanea pollen }\end{array}$ & $\begin{array}{c}\text { Chestnut decline due to the chestnut blight } \\
\text { peaked by } 1920 \text { in the region of Connecticut } \\
\text { located near Long Island }[44,45] \text {. Only the } \\
\text { portion of the age/depth range between the } \\
\text { assigned depth and the pollen sample above } \\
\text { it was used to determine consistency as } \\
\text { Castanea pollen dropped in abundance } \\
\text { between } 6 \text { and } 10 \mathrm{~cm} \text {. }\end{array}$ & $\begin{array}{c}10 \mathrm{~cm}, 6-10 \mathrm{~cm} \\
1960-1970\end{array}$ & No \\
\hline
\end{tabular}


Table 3. Cont.

\begin{tabular}{|c|c|c|c|c|c|c|}
\hline Site & $\begin{array}{l}\text { Pollen } \\
\text { Chronohorizon }\end{array}$ & $\begin{array}{c}\text { Pollen Chronohorizon } \\
\text { Age (CE) }\end{array}$ & Indicator & $\begin{array}{l}\text { Explanation of Chronohorizons Age and } \\
\text { Error, and Chosen Range for Date Analysis }\end{array}$ & $\begin{array}{l}\text { Depth, Range (cm) } \\
\text { Bchron Age (CE) }\end{array}$ & $\begin{array}{c}\text { Agreement between Pollen } \\
\text { Chronohorizons and } \\
\text { Bchron Predicted Age? }\end{array}$ \\
\hline New York & $\begin{array}{l}\text { Land clearance: } \\
\text { Initial (1a) } \\
{[41,71]}\end{array}$ & $1680 \pm 25$ & $\begin{array}{l}\text { Decrease in arboreal } \\
\text { pollen, such as Carya, } \\
\text { increase in Ambrosia } \\
\text { and Plantago }\end{array}$ & $\begin{array}{l}\text { Changes in pollen relevant to initial } \\
\text { deforestation can be dated to } \\
1680 \pm 25[41,71] \text {. The entire age/depth } \\
\text { range between the pollen sample above and } \\
\text { below was analyzed to determine consistency } \\
\text { as relevant pollen abundance changes } \\
\text { occurred on both sides of the depth assigned } \\
\text { to this chronohorizon. }\end{array}$ & $\begin{array}{c}59.5 \mathrm{~cm}, 54.5-64.5 \mathrm{~cm} \\
1655-1800\end{array}$ & Yes \\
\hline New York & $\begin{array}{c}\text { Land clearance: } \\
\text { Beginning of } \\
\text { the forestry } \\
\text { industry (1d) } \\
{[45,70]}\end{array}$ & $1825 \pm 25$ & $\begin{array}{l}\text { Strong decrease of } \\
\text { arboreal pollen, } \\
\text { increase of Plantago }\end{array}$ & $\begin{array}{l}1800 \text { is the start of the cordwood industry in } \\
\text { Long Island [45]. It is suggested that the } \\
\text { forestry industry in this region was active } \\
\text { starting in } 1800 \text { until } 1850 \text { [70]. The entire } \\
\text { age/depth range between the pollen sample } \\
\text { above and below was analyzed to determine } \\
\text { consistency as relevant pollen abundance } \\
\text { changes occurred on both sides of the depth } \\
\text { assigned to this chronohorizon. }\end{array}$ & $\begin{array}{c}49.5 \mathrm{~cm}, 46.5-54.5 \mathrm{~cm} \\
1755-1830\end{array}$ & Yes \\
\hline New York & $\begin{array}{c}\text { Reforestation (2a) } \\
{[72,73]}\end{array}$ & $1960 \pm 25$ & $\begin{array}{l}\text { Restoration of arboreal } \\
\text { pollen }\end{array}$ & $\begin{array}{l}\text { Timber industry activities reduced tree cover } \\
\text { until about 1939, and the basal area of forests } \\
\text { had doubled by } 1985 \text { [72,73]. The entire } \\
\text { age/depth range between the pollen sample } \\
\text { above and below was analyzed to determine } \\
\text { consistency as relevant pollen abundance } \\
\text { changes occurred on both sides of the depth } \\
\text { assigned to this chronohorizon. }\end{array}$ & $\begin{array}{c}16.5 \mathrm{~cm}, 13.5-19.5 \mathrm{~cm} \\
1950-1965\end{array}$ & Yes \\
\hline New Jersey & $\begin{array}{l}\text { Land clearance: } \\
\text { Initial (1a) } \\
{[74,75]}\end{array}$ & $1710 \pm 50$ & $\begin{array}{l}\text { Decrease in arboreal } \\
\text { pollen, increase in } \\
\text { Ambrosia }\end{array}$ & $\begin{array}{l}\text { The area near Cape May Courthouse was } \\
\text { settled between } 1695 \text { and } 1725 \text { [74,75]. This } \\
\text { was broadened to account for lag times. The } \\
\text { entire age/depth range between the pollen } \\
\text { sample above and below was analyzed to } \\
\text { determine consistency as relevant pollen } \\
\text { abundance changes occurred on both sides of } \\
\text { the depth assigned to this chronohorizon. }\end{array}$ & $\begin{array}{c}87.5 \mathrm{~cm}, 82.5-92.5 \mathrm{~cm} \\
1570-1670\end{array}$ & Yes \\
\hline
\end{tabular}


Table 3. Cont.

\begin{tabular}{|c|c|c|c|c|c|c|}
\hline Site & $\begin{array}{c}\text { Pollen } \\
\text { Chronohorizon }\end{array}$ & $\begin{array}{l}\text { Pollen Chronohorizon } \\
\text { Age (CE) }\end{array}$ & Indicator & $\begin{array}{l}\text { Explanation of Chronohorizons Age and } \\
\text { Error, and Chosen Range for Date Analysis }\end{array}$ & $\begin{array}{l}\text { Depth, Range (cm) } \\
\text { Bchron Age (CE) }\end{array}$ & $\begin{array}{c}\text { Agreement between Pollen } \\
\text { Chronohorizons and } \\
\text { Bchron Predicted Age? }\end{array}$ \\
\hline New Jersey & $\begin{array}{l}\text { Land clearance: } \\
\text { lowest amount of } \\
\text { forest cover (1c) } \\
{[25,36,37,76,77]}\end{array}$ & $1800 \pm 20$ & $\begin{array}{l}\text { Quercus:Ambrosia is } \\
\text { less than } 1.0\end{array}$ & $\begin{array}{l}\text { Many forests were clear-cut in Delaware and } \\
\text { New Jersey between } 1750 \text { and } 1850 \text { [76]. Coal } \\
\text { came into use in the region around } 1820 \text { as } \\
\text { firewood became scarce [77]. A date of } \\
1840 \pm 20 \text { is suggested for lowest forest cover } \\
\text { in Maryland [25,36]; however, in Delaware, } \\
\text { records suggest that } 1800 \text { is more } \\
\text { appropriate [37]. Only the portion of the } \\
\text { age/depth range between the assigned depth } \\
\text { and the pollen sample below it was used to } \\
\text { determine consistency as relevant changes in } \\
\text { pollen abundance occurred exclusively } \\
\text { between } 62.5 \text { and } 67.5 \mathrm{~cm} \text {. }\end{array}$ & $\begin{array}{c}62.5 \mathrm{~cm}, 62.5-67.5 \mathrm{~cm} \\
1825-1850\end{array}$ & No \\
\hline Delaware & $\begin{array}{c}\text { Land clearance: } \\
\text { Peak deforestation } \\
\text { for agriculture }(1 b) \\
{[25,36,37]}\end{array}$ & $1785 \pm 15$ & $\begin{array}{l}\text { Quercus:Ambrosia is } \\
\text { less than } 5.0\end{array}$ & $\begin{array}{l}\text { A date of } 1785+/-15 \text { years is suggested } \\
\text { based on palynological research in the } \\
\text { Chesapeake [25,36]. This is supported by a } \\
\text { summary of contemporaneous observations } \\
\text { of decreasing forest cover in the Delaware } \\
\text { region [37]. Only the portion of the } \\
\text { age/depth range between the assigned depth } \\
\text { and the pollen sample below it was used to } \\
\text { determine consistency as relevant changes in } \\
\text { pollen abundance occurred exclusively } \\
\text { between } 60 \text { and } 64 \mathrm{~cm} \text {. }\end{array}$ & $\begin{array}{l}60 \mathrm{~cm}, 60-64 \mathrm{~cm} \\
\quad 1795-1815\end{array}$ & Yes \\
\hline
\end{tabular}


Table 3. Cont.

\begin{tabular}{|c|c|c|c|c|c|c|}
\hline Site & $\begin{array}{l}\text { Pollen } \\
\text { Chronohorizon }\end{array}$ & $\begin{array}{c}\text { Pollen Chronohorizon } \\
\text { Age (CE) }\end{array}$ & Indicator & $\begin{array}{l}\text { Explanation of Chronohorizons Age and } \\
\text { Error, and Chosen Range for Date Analysis }\end{array}$ & $\begin{array}{l}\text { Depth, Range (cm) } \\
\text { Bchron Age (CE) }\end{array}$ & $\begin{array}{c}\text { Agreement between Pollen } \\
\text { Chronohorizons and } \\
\text { Bchron Predicted Age? }\end{array}$ \\
\hline Delaware & $\begin{array}{l}\text { Land clearance: } \\
\text { Lowest amount of } \\
\text { forest cover }(1 \mathrm{c}) \\
{[25,36,37,76,77]}\end{array}$ & $1800 \pm 20$ & $\begin{array}{l}\text { Quercus:Ambrosia is } \\
\text { less than } 1.0\end{array}$ & $\begin{array}{l}\text { Many forests were clear-cut in Delaware and } \\
\text { New Jersey between } 1750 \text { and } 1850 \text { [76]. Coal } \\
\text { came into use in the region around } 1820 \text { as } \\
\text { firewood became scarce [77]. A date of } \\
1840 \pm 20 \text { is suggested for lowest forest cover } \\
\text { in Maryland [25,36]; however, in Delaware, } \\
\text { records suggest that } 1800 \text { is more appropriate } \\
\text { [37]. Only the portion of the age/ depth range } \\
\text { between the assigned depth and the pollen } \\
\text { sample below it was used to determine } \\
\text { consistency as relevant changes in pollen } \\
\text { abundance occurred exclusively between } \\
62.5 \text { and } 67.5 \mathrm{~cm} \text {. }\end{array}$ & $\begin{array}{c}56 \mathrm{~cm}, 56-60 \mathrm{~cm} \\
1800-1820\end{array}$ & Yes \\
\hline Maryland & $\begin{array}{c}\text { Land clearance: } \\
\text { Peak deforestation } \\
\text { for agriculture }(1 b) \\
{[25,36]}\end{array}$ & $1785 \pm 15$ & $\begin{array}{l}\text { Quercus:Ambrosia is } \\
\text { less than } 1.0\end{array}$ & $\begin{array}{l}\text { A date of } 1785+/-15 \text { years is suggested } \\
\text { based on palynological research in the } \\
\text { Chesapeake }[25,36] \text {. Only the portion of the } \\
\text { age/depth range between the assigned depth } \\
\text { and the pollen sample below it was used to } \\
\text { determine consistency as relevant changes in } \\
\text { pollen abundance occurred exclusively } \\
\text { between } 52 \text { and } 56 \mathrm{~cm} \text {. }\end{array}$ & $\begin{array}{c}52 \mathrm{~cm}, 52-56 \mathrm{~cm} \\
1740-1805\end{array}$ & Yes \\
\hline Maryland & $\begin{array}{c}\text { Land clearance: } \\
\text { Lowest amount of } \\
\text { forest cover }(1 \mathrm{c}) \\
{[25,36]}\end{array}$ & $1840 \pm 20$ & $\begin{array}{l}\text { Ambrosia reaches its } \\
\text { highest abundance }\end{array}$ & $\begin{array}{l}\text { A date of } 1840 \pm 20 \text { for lowest forest cover is } \\
\text { suggested in Maryland }[25,36] \text {. The entire } \\
\text { age/depth range between the pollen sample } \\
\text { above and below was analyzed to determine } \\
\text { consistency as peak Ambrosia abundance may } \\
\text { have occurred on either side of the depth } \\
\text { assigned to this chronohorizon. }\end{array}$ & $\begin{array}{l}32 \mathrm{~cm}, 30-34 \mathrm{~cm} \\
1875-1915\end{array}$ & No \\
\hline $\begin{array}{l}\text { North } \\
\text { Carolina }\end{array}$ & $\begin{array}{l}\text { Land clearance: } \\
\text { Initial (1a) } \\
{[26,44,64]}\end{array}$ & $1720 \pm 20$ & $\begin{array}{l}\text { Decrease in arboreal } \\
\text { pollen, increase in } \\
\text { Ambrosia }\end{array}$ & $\begin{array}{l}\text { The decrease in Ambrosia pollen is an } \\
\text { indicator of settlement }[44,64] \text { and settlement } \\
\text { is associated with a date of } 1720 \pm 20[26] \text {. } \\
\text { The entire age/depth range between the } \\
\text { pollen sample above and below was analyzed } \\
\text { to determine consistency as relevant pollen } \\
\text { abundance changes occurred on both sides of } \\
\text { the depth assigned to this chronohorizon. }\end{array}$ & $\begin{array}{c}70 \mathrm{~cm}, 65-75 \mathrm{~cm} \\
1610-1750\end{array}$ & Yes \\
\hline
\end{tabular}


Table 3. Cont.

\begin{tabular}{|c|c|c|c|c|c|c|}
\hline Site & $\begin{array}{l}\text { Pollen } \\
\text { Chronohorizon }\end{array}$ & $\begin{array}{l}\text { Pollen Chronohorizon } \\
\text { Age (CE) }\end{array}$ & Indicator & $\begin{array}{l}\text { Explanation of Chronohorizons Age and } \\
\text { Error, and Chosen Range for Date Analysis }\end{array}$ & $\begin{array}{l}\text { Depth, Range (cm) } \\
\text { Bchron Age (CE) }\end{array}$ & $\begin{array}{c}\text { Agreement between Pollen } \\
\text { Chronohorizons and } \\
\text { Bchron Predicted Age? }\end{array}$ \\
\hline N. Florida & $\begin{array}{l}\text { Land clearance: } \\
\text { Railroad } \\
\text { expansion (1e) } \\
{[78]}\end{array}$ & $1865 \pm 15$ & $\begin{array}{l}\text { Decrease in arboreal } \\
\text { pollen, increase in } \\
\text { Ambrosia }\end{array}$ & $\begin{array}{l}\text { Construction of railroads in Florida began in } \\
\text { 1854, expanded following the Civil War, and } \\
\text { were completed in } 1881 \text { [78]. Only the } \\
\text { portion of the age/depth range between the } \\
\text { assigned depth and the pollen sample below } \\
\text { it was used to determine consistency as } \\
\text { relevant changes in pollen abundance } \\
\text { occurred exclusively between } \\
20.5 \text { and } 21.5 \mathrm{~cm} \text {. }\end{array}$ & $\begin{array}{c}20.5 \mathrm{~cm}, 20.5-21.5 \mathrm{~cm} \\
1880-1905\end{array}$ & Yes \\
\hline N. Florida & $\begin{array}{l}\text { Land clearance: } \\
\text { Beginning of } \\
\text { the forestry } \\
\text { industry }(1 \mathrm{~d}) \\
{[27,79]}\end{array}$ & $1935 \pm 10$ & $\begin{array}{c}\text { Decrease in Pinus and } \\
\text { Quercus, Increase in } \\
\text { Ambrosia }\end{array}$ & $\begin{array}{l}\text { The forestry industry in Florida started in } \\
1935 \text { [79]. The error for this chronohorizon } \\
\text { should be } 10 \text { years [27]. The entire age/depth } \\
\text { range between the pollen sample above and } \\
\text { below was analyzed to determine consistency } \\
\text { as relevant pollen abundance changes } \\
\text { occurred on both sides of the depth assigned } \\
\text { to this chronohorizon. }\end{array}$ & $\begin{array}{c}12.5 \mathrm{~cm}, 10.5-13.5 \mathrm{~cm} \\
1940-1970\end{array}$ & Yes \\
\hline S. Florida & $\begin{array}{c}\text { Introduction or loss } \\
\text { of taxa Casuarina } \\
\text { introduction }(3 b) \\
{[65,66,79,80]}\end{array}$ & $1910 \pm 15$ & $\begin{array}{l}\text { Appearance of } \\
\text { Casuarina pollen }\end{array}$ & $\begin{array}{l}\text { This chronohorizon is defined as the } \\
\text { appearance of Casuarina pollen }[65,66] \text {. The } \\
\text { timing was determined by using } \\
\text { literature-derived values of } 1900 \text { [80] and } \\
1910+/-15 \text { years [79]. Only the portion of } \\
\text { the age/depth range between the assigned } \\
\text { depth and the pollen sample below it was } \\
\text { used to determine consistency as Casuarina } \\
\text { appeared between } 25.5 \text { and } 29.5 \mathrm{~cm} \text {. }\end{array}$ & $\begin{array}{c}25.5 \mathrm{~cm}, 25.5-29.5 \mathrm{~cm} \\
1750-1885\end{array}$ & No \\
\hline S. Florida & $\begin{array}{c}\text { Land Clearance: } \\
\text { Beginning of } \\
\text { the forestry } \\
\text { industry (1d) } \\
{[27,78]}\end{array}$ & $1935 \pm 10$ & $\begin{array}{l}\text { Decrease in Pinus } \\
\text { pollen }\end{array}$ & $\begin{array}{l}\text { The forestry industry in Florida started in } \\
1935 \text { [78]. The error for this chronohorizon } \\
\text { should be } 10 \text { years [27]. Only the portion of } \\
\text { the age/depth range between the assigned } \\
\text { depth and the pollen sample above it was } \\
\text { used to determine consistency as Pinus } \\
\text { pollen dropped between } 9.5 \text { and } 13.5 \mathrm{~cm} \text {. }\end{array}$ & $\begin{array}{l}13.5 \mathrm{~cm}, 9.5-13.5 \mathrm{~cm} \\
1895-1945\end{array}$ & Yes \\
\hline
\end{tabular}




\subsubsection{Radiocarbon}

We performed radiocarbon analyses at all unpublished sites on identifiable plant macrofossils from sediment cores using the National Ocean Sciences Accelerator Mass Spectrometry (NOSAMS) facility at Woods Hole. At all sites, we extracted plant macrofossils (e.g., Spartina and Juncus) to reduce risk of older or younger contamination in bulk sediments, and selected surface markers likely to be in situ. We removed contaminating materials, such as extraneous particles, from the plant macrofossils by cleaning the specimen under a dissection microscope [57]. The radiocarbon samples also underwent acid-baseacid pretreatment prior to analysis to further remove contaminants [57]. Radiocarbon ages from NOSAMS were calibrated in Bchron using IntCal13 calibration data set [12,81]. Radiocarbon chronologies of published studies are found in the original publications (Table 1). Radiocarbon chronologies and Bchron-calibrated age ranges of unpublished studies are found in Table 2.

\subsubsection{Radionuclide ${ }^{137} \mathrm{Cs}$}

The fallout radionuclide ${ }^{137} \mathrm{Cs}\left(\mathrm{t}_{1 / 2}=30.2\right.$ years) has been extensively used to provide estimates of age with depth in a sediment column. ${ }^{137} \mathrm{Cs}$ is an artificially produced radionuclide present in the environment due to atmospheric fallout from atmospheric nuclear weapons testing, reactor accidents, and discharges from nuclear facilities. Global dispersion and fallout of ${ }^{137} \mathrm{Cs}$ began in $1954 \mathrm{CE}$ following the detonation of high-yield thermonuclear weapons with a distinct maximum in fallout in $1963 \mathrm{CE}[23,82,83]$. These two dates (i.e., 1954, 1963 CE) provide an initial appearance and subsurface activity maximum in accumulating sediments and are used to assign an age to a specific depth in the sediment column.

Sediment samples were dried at $60{ }^{\circ} \mathrm{C}$ in an oven to determine dry bulk density and water content. The sampling increment was 1 to $2 \mathrm{~cm}$ in Delaware, $2 \mathrm{~cm}$ in Maryland, and 1 to $2 \mathrm{~cm}$ in southern Florida. We measured ${ }^{137} \mathrm{Cs}$ activities via gamma spectroscopy. Prior to analysis, samples were homogenized, packed into standardized vessels, and measured via gamma emissions for at least $24 \mathrm{~h}$. Gamma counting was conducted on low-background, high-efficiency, high-purity Germanium detectors coupled with a multi-channel analyzer. Detectors were calibrated using natural matrix standards (IAEA-300, 312, 314) at the energy of interest $(661 \mathrm{keV})$ in the standard counting geometry for the associated detector.

\subsubsection{Pollution Markers}

We analyzed sediments for pollutants with known deposition chronologies to provide further chronological constraints during the past $~ 150$ years. Metal concentrations were analyzed to identify key pollutant horizons relative to each site. While these age markers are region specific, some examples include: (1) the peak and decline of ${ }^{206} \mathrm{~Pb}$ and ${ }^{207} \mathrm{~Pb}$, released from coal burning, in 1858 and $1880 \mathrm{CE}$ associated with lead production in the Upper Mississippi Valley (UMV) [35,84,85]; (2) lead ( $\mathrm{Pb})$ pollution associated with manufacturing and later, with gasoline from vehicles, beginning in $1875 \mathrm{CE}$, peaking in $1974 \mathrm{CE}$, and declining in $1980 \mathrm{CE}$ [86]; (3) the onset of copper $(\mathrm{Cu})$ pollution, which occurred around $1900 \mathrm{CE}[87,88]$; (4) the decline of cadmium (Cd) and nickel (Ni) pollution, which occurred around 1975 and 1997 CE, respectively [32,57]; and (5) an arsenic (As) peak in Florida in 1970 CE [31]. Core depths, dates, and uncertainty for relevant pollution chronohorizons at each site are detailed in Table 2 and in Appendix A.

For published studies, the methodology for preparation of samples for pollution markers can be found in the original publications (Table 2). Sediment samples from unpublished sites were digested using the modified EPA method 3051 for microwaveassisted acid digestion. First, $10 \mathrm{~mL} \mathrm{HNO}_{3}$ were added to the $0.5 \mathrm{~g}$ sediment sample. After pre-digestion for two hours at room temperature, vessels were sealed and placed in a MiniWAVE microwave digestion system (SCP Science, Baie D'Urfé, QC, Canada). After digestion, samples were diluted with $50 \mathrm{~mL}$ ultrapure DI water. An Inductively Coupled Plasma-Mass Spectrometer (ICP-MS; Agilent 7700X, Palo Alto, CA, USA) was 
used for measurement of metal and other element concentrations in the sample digests. We observed changes in several pollutants throughout the core to determine chronohorizons associated with them. We used initial increases in metal concentrations in cores to identify onset pollution chronohorizons and the highest concentrations of the metals to identify peak pollution chronohorizons. The chronologies from radiocarbon, radionuclide ${ }^{137} \mathrm{Cs}$ and pollution markers of unpublished studies are found in Table 2.

\subsubsection{Bayesian Inferences}

We used Bchron [54] to examine (1) the accuracy of pollen chronohorizons; (2) the impact of pollen chronohorizons on the precision of age-depth models; and (3) the impact of pollen chronohorizons on the Bchron-predicted age-depth relationship.

Bchron is a Bayesian Chronology package that runs in R [89,90]. All available data (i.e., including older radiocarbon dates) were included in the statistical analyses, although we only show Bchron age-depth models from a median age of $1500 \mathrm{CE}$ to present (Tables 1 and 2) to encompass the portion of the model that may have been impacted by pollen chronohorizons. Age-depth models were developed for datasets with radiocarbon, radionuclide ${ }^{137} \mathrm{Cs}$, and pollution age markers combined with pollen (WP) and no pollen (NP) to assess the accuracy of the pollen chronohorizons. We set the prior probability of outliers to $5 \%$ for radiocarbon dates [91] and 1\% for other age markers. Due to the complexity of these models, especially with respect to convergence given the multi-model dates and outlier combinations, we ran 31 replicate runs of 100,000 iterations for each chronology and used these to create posterior medians and 50\% uncertainty intervals (UI). We used $50 \%$ UI because these are much more robustly estimated than standard $95 \%$ or $99 \%$ intervals [92]. We ran 31 replicate simulations in order to ensure that the Bayesian model used by Bchron samples properly from the probability distribution (known as the posterior) and that our results are reproducible. At convergence, when the 31 replicate simulations produce similar outputs, the 31 replicate simulations can be treated as independent and identically distributed samples from the age-depth posterior probability distribution.

Our strategy to determine the consistency of pollen chronohorizons required several steps. First, we compared the age of pollen chronohorizons from journals, letters, and almanacs to the age estimated by the Bchron NP model (Figure 4, Table 3). We then identified the depth of the chronohorizon and compared this depth to the Bchron-predicted age of the corresponding depth in the NP model. Finally, we concluded that a pollen chronohorizon was consistent if its age, plus uncertainty, overlapped with the Bchron $\mathrm{NP}$ reconstructed age range within the $50 \%$ UI for the sampling interval in which the pollen chronohorizon was found. When making these comparisons, the full width of the uncertainty assigned to each pollen chronohorizon reference date was considered in order to account for regional variations and signal lag times (Figure 4, Appendix C).

Second, to identify the impact of pollen chronohorizons on the precision of age-depth models, we calculated the difference between the median 50\% UI width of the NP and WP models. This was done for the individual pollen chronohorizons and for all pollen chronohorizons combined at each site, for a total of 24 models. Due to the accumulation model used by Bchron, pollen chronohorizons impacted the age-depth model not only at their identified depth, but also at surrounding depths. We focused our comparison between models on the area most influenced by the pollen chronohorizon: (a) the interval between the pollen chronohorizons and the nearest age marker, or (b) the interval $5 \mathrm{~cm}$ above or below the pollen chronohorizon of interest, whichever was larger. Comparisons including multiple pollen chronohorizons were analyzed from the age marker above the shallowest pollen chronohorizon to the age marker below the deepest pollen chronohorizon. We compared the measured widths of the 50\% UIs of WP and NP swaths averaged over the defined interval to identify how pollen chronohorizons impacted the precision of age-depth models. We reported the differences between $50 \%$ UI swaths of WP and NP models in years and identified average differences of less than five years as representing "no change" (Figure 5, Table 4). 

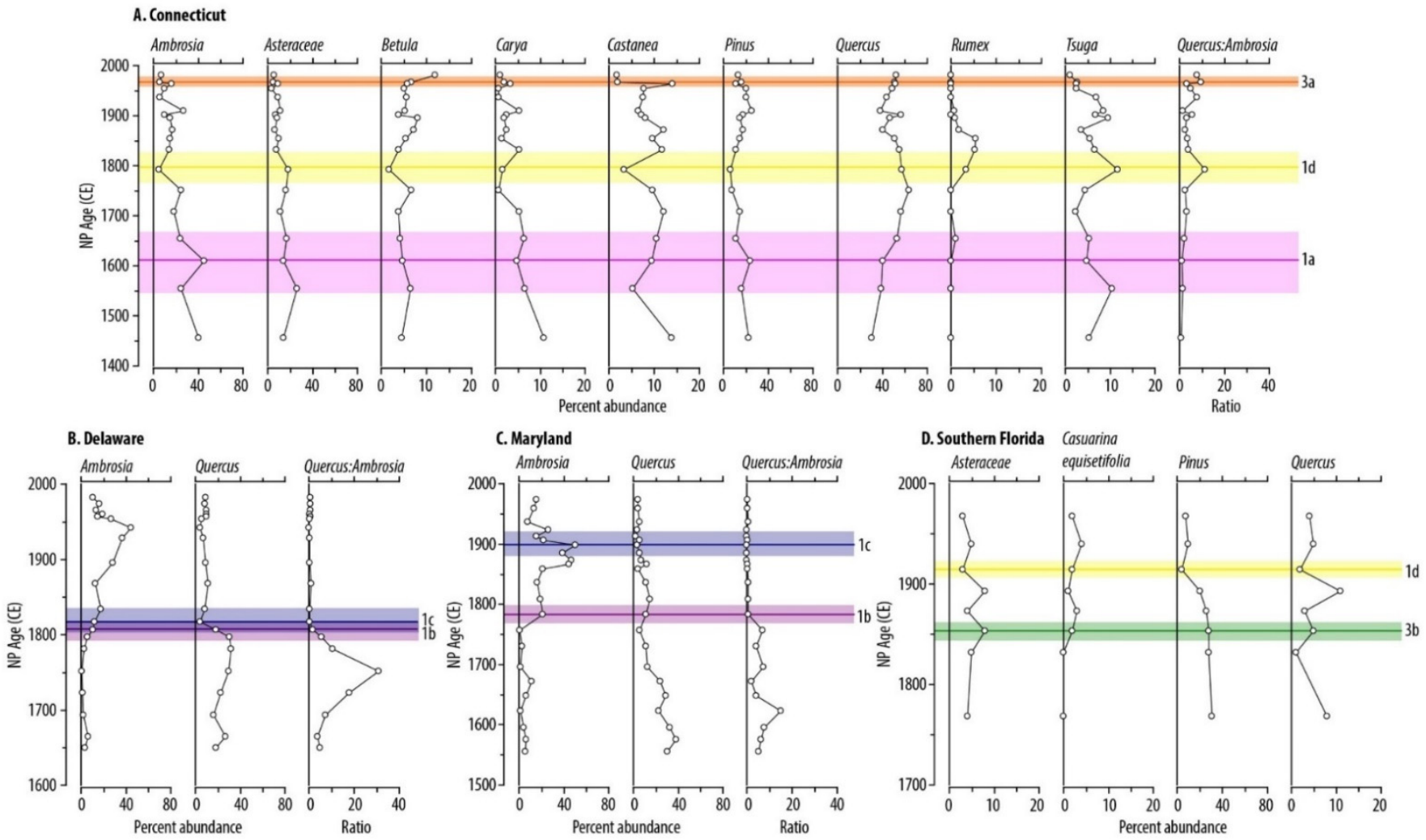

Figure 4. Pollen stratigraphic diagrams plotted against the NP Bchron predicted ages to compare the age plus uncertainty of the pollen chronohorizons with the ages derived from other age markers at the depth where the pollen chronohorizon occurred for Connecticut (A), Delaware (B), Maryland (C), and Southern Florida (D). Lines indicate the pollen chronohorizons; shading indicates the uncertainty associated with each pollen chronohorizon. The chronohorizons are as follows: (3a) chestnut blight; (1d) beginning of the forestry industry; (1a) initial land clearance; (1c) lowest amount of forest cover; (1b) peak deforestation; and (3b) Casuarina introduction (Table 3). 


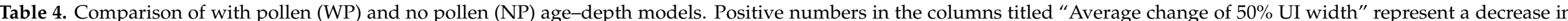

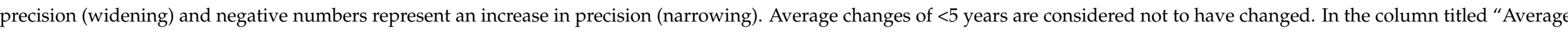

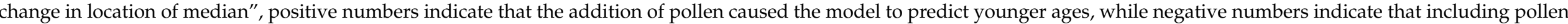
caused the model to predict older ages for sediments in the depth range listed.

\begin{tabular}{|c|c|c|c|c|c|c|}
\hline Site & Pollen Chronohorizon & $\begin{array}{l}\text { Depth Range for Pollen } \\
\text { Chronohorizon } \\
\text { (cm) }\end{array}$ & $\begin{array}{l}\text { Average Change of } 50 \% \\
\text { UI Width (years) }\end{array}$ & Improved Precision? & $\begin{array}{c}\text { Average Change in } \\
\text { Location of Median } \\
\text { (Years) }\end{array}$ & Location Change? \\
\hline Connecticut & (1a) Initial land clearance & $56-66$ & +5 & No & +19 & Yes \\
\hline Connecticut & (1d) Beginning of the forestry industry & $43-56$ & -7 & Yes & +5 & Yes \\
\hline Connecticut & (3a) Chestnut blight & $5-15$ & $<5$ & & $<5$ & No \\
\hline Connecticut & All chronohorizons & $5-66$ & $<5$ & & +5 & Yes \\
\hline New York & (1a) Initial land clearance & $51-70$ & $<5$ & & -9 & Yes \\
\hline New York & (1d) Beginning of the forestry industry & $41-51$ & $<5$ & & $<5$ & No \\
\hline New York & (2a) Reforestation & $10-20$ & $<5$ & & $<5$ & No \\
\hline New York & All chronohorizons & $10-70$ & $<5$ & & -7 & Yes \\
\hline New Jersey & (1a) Initial land clearance & $68-94$ & +14 & No & +8 & Yes \\
\hline New Jersey & (1c) Lowest amount of forest cover & $59-69$ & $<5$ & & $<5$ & No \\
\hline New Jersey & All chronohorizons & $59-94$ & +9 & No & $<5$ & No \\
\hline Delaware & (1c) Lowest amount of forest cover & $53-67$ & +8 & No & -6 & Yes \\
\hline Delaware & All chronohorizons & $53-67$ & +16 & No & -18 & Yes \\
\hline Maryland & (1b) Peak deforestation for agriculture & $10-62$ & -5 & Yes & $<5$ & No \\
\hline Maryland & (1c) Lowest amount of forest cover & $10-62$ & $<5$ & & $<5$ & No \\
\hline Maryland & All chronohorizons & $10-62$ & -6 & Yes & $<5$ & No \\
\hline North Carolina & (1a) Initial land clearance & $60-80$ & -20 & Yes & +20 & Yes \\
\hline
\end{tabular}


Table 4. Cont

\begin{tabular}{|c|c|c|c|c|c|c|}
\hline Site & Pollen Chronohorizon & $\begin{array}{c}\text { Depth Range for Pollen } \\
\text { Chronohorizon } \\
(\mathrm{cm})\end{array}$ & $\begin{array}{l}\text { Average Change of } 50 \% \\
\text { UI Width (years) }\end{array}$ & Improved Precision? & $\begin{array}{c}\text { Average Change in } \\
\text { Location of Median } \\
\text { (Years) }\end{array}$ & Location Change? \\
\hline N. Florida & (1e) Railroad expansion & $15-25$ & $<5$ & & $<5$ & No \\
\hline N. Florida & (1d) Beginning of the forestry industry & $7-17$ & $<5$ & & $<5$ & No \\
\hline N. Florida & All chronohorizons & $7-25$ & $<5$ & & $<5$ & No \\
\hline S. Florida & (3b) Casuarina introduction & $8-26$ & -40 & Yes & +28 & Yes \\
\hline S. Florida & (1d) Beginning of the forestry industry & $8-26$ & -19 & Yes & $<5$ & No \\
\hline S. Florida & All chronohorizons & $8-26$ & -41 & Yes & +23 & Yes \\
\hline
\end{tabular}




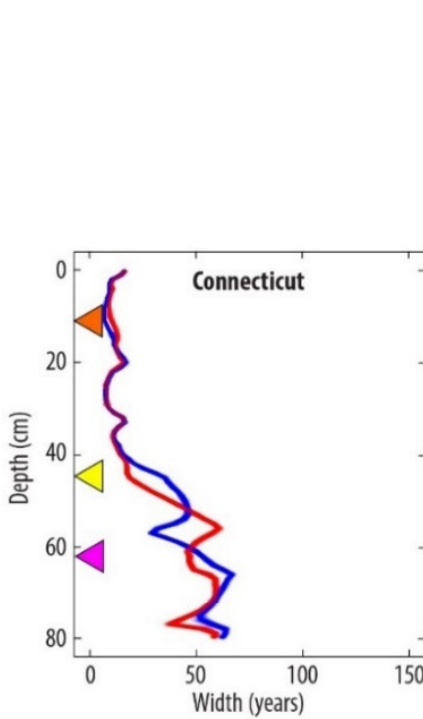

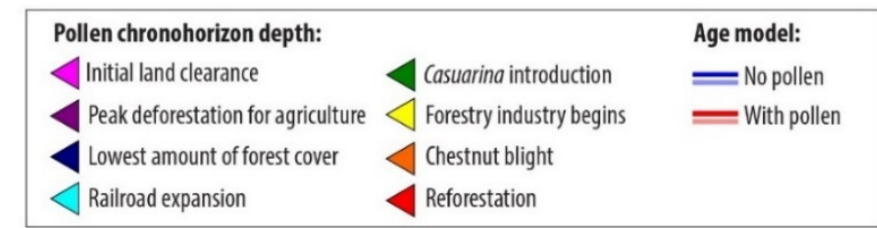
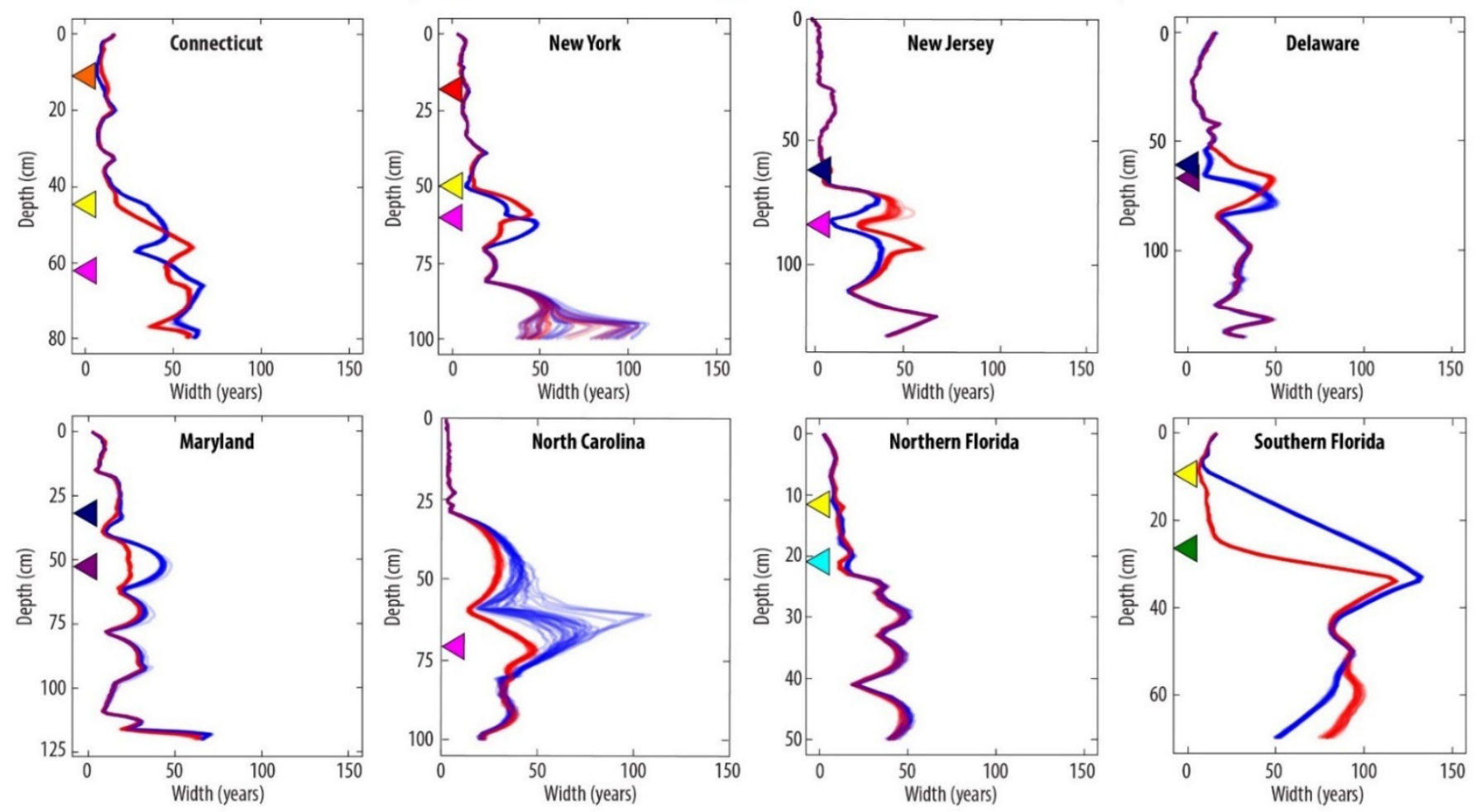

Figure 5. Comparison of the difference in width of the 50\% UI between the WP (all chronohorizon in red) and NP (blue) models over the interval from $1500 \mathrm{CE}$ through the present (see also Figure A2). The red and blue lines are plotted transparently so that lighter areas represent widths that are predicted less frequently by Bchron, while darker areas represent widths that are predicted more frequently. The depth of the pollen chronohorizons is plotted using colored triangles which correspond to Figure 3.

Third, to identify the impact of pollen chronohorizons on the Bchron-predicted agedepth relationship, we compared the position of the median age-depth model for WP and NP models, calculated based on the medians of the 31 replicate models. We determined the difference between the median of the NP and WP models, and compared them across the depth most influenced by the pollen chronohorizon(s) included in the model, as described above (Figure 6, Table 4). We found the average of these differences and report where the difference is in excess of five years as above. 


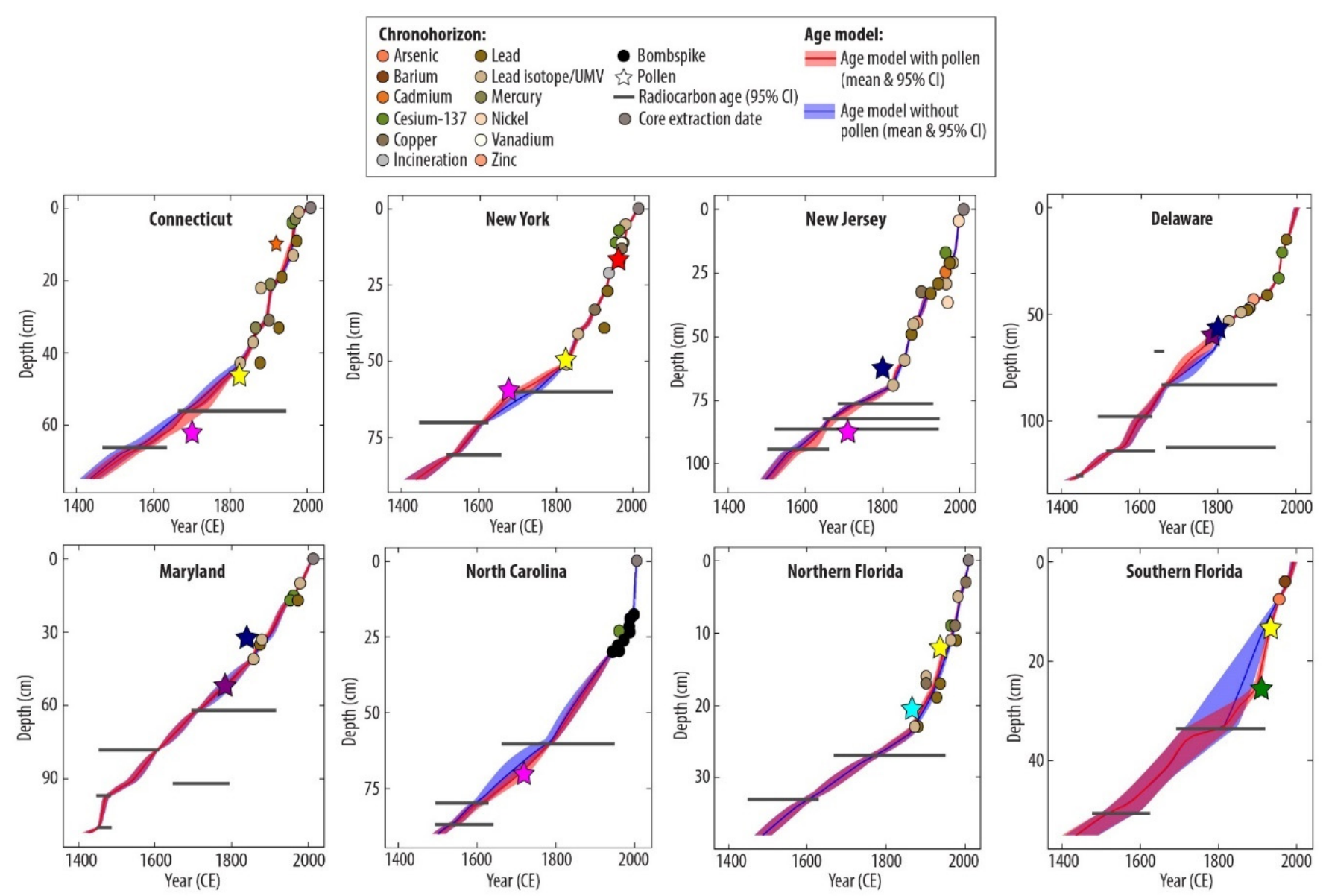

Figure 6. Median Bchron age-depth models for all study sites with 50\% UIs showing the WP model in red and the NP model in blue. These were calculated based on the median of all 31 replicates. UMV refers to lead pollution originating in the Upper Mississippi Valley.

\section{Results}

\subsection{Connecticut}

In Connecticut, we documented three pollen chronohorizons.

(1a) Initial land clearance associated with European settlement in $1700 \pm 60 \mathrm{CE}$ corresponds to a NP-predicted age range of 1515 to $1670 \mathrm{CE}$, indicating that the pollen chronohorizon is consistent with the ages predicted by the NP Bchron age-depth model (Figure 3, Table 3). The initial land clearance horizon increased the width of the 50\% UI swath by 5 years and changed the position of the median age-depth model by +19 years (Figure 5, Table 4).

(1d) The beginning of the forestry industry in $1825 \pm 25 \mathrm{CE}$ is consistent with the NP-predicted age range of 1730 to 1840 CE (Figure 3, Table 3). The forestry industry signal narrowed the $50 \%$ UI swath by 7 years in the portion of the core surrounding the depth where it was documented (Figure 5, Table 4, Appendix B) and changed the position of the median age-depth model by +5 years (Table 4 ).

(3a) The chestnut blight chronohorizon in $1920 \pm 10 \mathrm{CE}$ is inconsistent with an NPpredicted age range of 1960 to 1970 CE in the NP age-depth model (Figure 3, Table 3). The chestnut blight chronohorizon did not change the width of the $50 \%$ UI swath ( $<5$ years) (Figure 5, Table 4, Appendix B) or the position of the median Bchron age-depth model (<5 years) (Table 4$)$.

Finally, we combined all three chronohorizons into a single age-depth model. The width of the $50 \%$ UI swath did not change ( $<5$ years) (Figure 5 , Table 4 ) but the position of the median age-depth model changed by +5 years (Figure 6 , Table 4 ). 


\subsection{New York}

In New York, we documented three pollen chronohorizons.

(1a) Initial land clearance in $1680 \pm 25 \mathrm{CE}$ is consistent with the NP predicted age range of 1655 to $1800 \mathrm{CE}$ (Table 3, Appendix C). Including this chronohorizon did not change the width of the $50 \%$ UI swath $(<5$ years); however, the position of the median age-depth model changed by -9 years (Figure 5, Table 4, Appendix B).

(1d) The beginning of the forestry industry in $1825 \pm 25 \mathrm{CE}$ has an NP-predicted age range of 1755 to $1835 \mathrm{CE}$, which is consistent with the other chronometers (Table 3, Appendix C). When this chronohorizon was included in the Bchron age-depth model, neither the width of the $50 \%$ UI swath nor the position of the median age-depth model position changed (both $<5$ years) (Figure 5 , Table 4 , Appendix B)

(2a) Reforestation in $1960 \pm 25 \mathrm{CE}$ is associated with an NP-predicted age range of 1950 to $1965 \mathrm{CE}$, indicating that the pollen chronohorizon is consistent with other chronometers (Table 3, Appendix C). When the reforestation chronohorizon was included in the age-depth model, neither the width of the $50 \%$ UI swath nor the position of the median age-depth model changed (both $<5$ years) (Figure 5, Table 4, Appendix B).

When all three pollen chronohorizons were included in the Bchron age-depth model, the width of the $50 \%$ UI swath did not change ( $<5$ years) (Figure 5, Table 4$)$. The position of the median age-depth model changed by -7 years (Figure 6 , Table 4 ).

\subsection{New Jersey}

In New Jersey, we documented two pollen chronohorizons.

(1a) The timing of initial land clearance in New Jersey in $1710 \pm 50 \mathrm{CE}$ is consistent with the NP-predicted age range of 1570 to 1670 CE (Table 3, Appendix C). Including this chronohorizon in the age-depth model increased the width of the $50 \%$ UI swath by 14 years and changed the position of the median age-depth model by +8 years (Figure 5, Table 4, Appendix B).

(1c) The chronohorizon associated with the lowest amount of forest cover during a regional wood shortage that occurred in $1800 \pm 20 \mathrm{CE}$ is inconsistent with the NP-predicted age range of 1825 to $1850 \mathrm{CE}$ (Table 3, Appendix C). When we included this chronohorizon in the Bchron age-depth model, neither the width of the $50 \%$ UI swath nor the position of the median age-depth model changed ( $<5$ years) (Figure 5, Table 4, Appendix B).

The inclusion of both chronohorizons in the age-depth model increased the width of the $50 \%$ UI swath by 9 years (Figure 5, Table 4). Including these chronohorizons did not change the position of the median age-depth model predicted by Bchron $(<5$ years $)$ (Figure 6, Table 4).

\subsection{Delaware}

In Delaware, we documented two pollen chronohorizons.

(1b) The chronohorizon associated with peak deforestation for agriculture in $1785 \pm 15$ $\mathrm{CE}$ is consistent with the NP-predicted age range of 1795 to $1815 \mathrm{CE}$ (Figure 3, Table 3). The inclusion of this chronohorizon increased the width of the $50 \%$ UI swath by 11 years (Figure 5, Table 4, Appendix B) and changed the position of the median age-depth model by -7 years (Table 4 ).

(1c) The chronohorizon corresponding to the lowest amount of forest cover in $1800 \pm 20$ $\mathrm{CE}$ is consistent with an NP-predicted age range of 1800 to $1820 \mathrm{CE}$ in the NP model (Figure 4, Table 3). When we included this chronohorizon in the Bchron age-depth model, the width of the $50 \%$ UI swath increased by 8 years and the position of the median age depth model changed by -6 years (Figure 5 , Table 4 , Appendix B).

The inclusion of both chronohorizons in the age-depth model increased the width of the $50 \%$ UI swath by 9 years (Figure 5, Table 4). Including these chronohorizons also changed the position of the median age-depth model predicted by Bchron by -18 years (Figure 6, Table 4). 


\subsection{Maryland}

In Maryland, we documented two pollen chronohorizons.

(1b) The chronohorizon associated with peak deforestation for agriculture in $1785 \pm 15$ $\mathrm{CE}$ is consistent with an NP-predicted age range of 1740 to $1805 \mathrm{CE}$ (Figure 4, Table 3). Including this chronohorizon decreased the width of the $50 \%$ UI swath by 5 years but did not change the position of the median age-depth model ( $<5$ years) (Figure 5, Table 4 , Appendix B).

(1c) The chronohorizon associated with the lowest amount of forest cover occurred in $1840 \pm 20 \mathrm{CE}$ and is inconsistent with the NP Bchron predicted age range of 1875 to 1915 CE (Figure 4, Table 3). When this chronohorizon was included in the age-depth model, neither the width of the $50 \%$ UI swath nor the position of the median age-depth model changed (both $<5$ years) (Figure 5, Table 4, Appendix B).

The inclusion of both chronohorizons in the age-depth model decreased the width of the $50 \%$ UI swath by 6 years (Figures 5 and 6 , Table 4 ). The inclusion of these chronohorizons did not change the position of the median age-depth model predicted by Bchron (Figures 5 and 6, Table 4).

\subsection{North Carolina}

We documented one pollen chronohorizon in North Carolina.

(1a) Initial land clearance in North Carolina occurred in $1720 \pm 20 \mathrm{CE}$, which is consistent with the NP-predicted age range of 1610 to 1750 CE (Table 3, Appendix C). The inclusion of the initial land clearance chronohorizon decreased the width of the $50 \%$ UI swath by 20 years and changed the position of the median age-depth model by +20 years (Figures 5 and 6, Table 4, Appendix B).

\subsection{Northern Florida}

We documented two pollen chronohorizons in northern Florida.

(1e) A chronohorizon associated with land clearance for railroad expansion in $1865 \pm 15$ CE is consistent with the NP-predicted age range of 1880 to 1905 CE (Table 3, Appendix C). When this chronohorizon was included in age-depth models, neither the width of the $50 \%$ UI swath nor the position of the median age-depth model changed (both $<5$ years) (Figure 5 , Table 4, Appendix B).

(1d) The chronohorizon associated with the beginning of the forestry industry in $1935 \pm 10 \mathrm{CE}$ is associated with an NP-predicted age range of 1940 to $1970 \mathrm{CE}$, which is consistent between the pollen chronohorizon and other age markers (Table 3, Appendix C). When this chronohorizon is included in the age-depth model, neither the width of the $50 \%$ UI swath nor the position of the median age-depth model changed (both $<5$ years) (Figure 5, Table 4, Appendix B).

The inclusion of both chronohorizons in the age-depth model did not change the width of the $50 \%$ UI swath ( $<5$ years) (Figure 6, Table 4 ). Additionally, including the combined age markers did not change the position of the median age-depth model ( $<5$ years) (Figure 5 , Table 4).

\subsection{Southern Florida}

We documented two pollen chronohorizons in southern Florida.

(3b) The chronohorizon associated with the introduction of Casuarina pollen in $1910 \pm 15$ $\mathrm{CE}$ is inconsistent with the NP-predicted age range of 1750 to $1885 \mathrm{CE}$ (Figure 4, Table 3). When the Casuarina chronohorizon was included, it decreased the width of the $50 \%$ UI swath by 40 years (Figure 5, Table 4 ) and changed the position of the median age-depth model by +28 years (Table 4 ).

(1d) The chronohorizon associated with the beginning of the forestry industry resulting in the removal of Dade Pines from the Keys in $1935 \pm 10 \mathrm{CE}$ is consistent with the NPpredicted age range from 1895 to 1945 CE (Figure 4, Table 3). When we included this 
chronohorizon, it decreased the width of the $50 \%$ UI swath by 19 years but did not change the position of the median age-depth model ( $<5$ years) (Figure 5, Table 4, Appendix B).

The inclusion of both chronohorizons greatly improved the Bchron age-depth model (Figure 6, Table 4): the width of the 50\% UI swath decreased by 41 years. Additionally, the position of the median age-depth estimate changed by +23 years (Figure 5, Table 4 , Appendix B).

\section{Discussion}

Pollen assemblages have been applied as chronometers throughout the Holocene [40], particularly during the last 500 years where the timing of events such as initial land clearance, industrial forestry, and recent importation or losses of taxa, help define anthropogenic alterations of the environment $[25,40,44,79]$. However, the application of pollen chronohorizons should proceed with caution in salt marsh environments, due to hyperlocality $[40,63]$, sediment mixing [93-95], misinterpretation of pollen signals [74,75,96,97], and/or incorrect pollution and radiocarbon dates [98-101].

\subsection{Validation of Pollen Chronohorizons}

We validated the consistency of the pollen chronohorizons with other age markers by comparing the age ranges of pollen reference dates with Bchron age-depth models without pollen. While the majority of pollen chronohorizons were consistent with other age markers, four were inconsistent. Thirteen out of 17 pollen chronohorizons applied to cores were consistent with the chronology produced using the NP Bchron age-depth model (Table 3). Four pollen chronohorizons applied to cores were inconsistent with the NP chronology: the lowest amount of forest cover in Maryland; chestnut blight in Connecticut; the appearance of Casuarina in southern Florida; and the lowest amount of forest cover in New Jersey (Figure 4, Appendix C).

Pollen chronohorizons may be assigned an incorrect reference date due to hyperlocality (location-specific vegetation changes) and variations in regional signals [26,40,44,64,102]. The dispersal methods used by pollen can influence whether a signal is local or regional. Wind dispersal mechanisms are governed by atmospheric flow dynamics, landscape heterogeneity and climate, and differ among and within taxa because not all pollen grains are created equal $[40,68,103,104]$. It is well known that Pinus can be transported hundreds of kilometers [105], but models have shown that Ambrosia can also be transported hundreds of kilometers, suggesting that the Ambrosia pollen that we see in our cores may be local or regional $[106,107]$. In contrast, the pollen of Plantago and many other land-cover plants are transported only tens of meters. Therefore, when identifying a chronohorizon, the distance from the reference site should be considered when choosing which taxa to use [68,107]. Pollen transportation distances and production can also lead to specific, small localities having different timing or signals for chronohorizons, or hyperlocal effects $[40,63]$. Therefore, palynological changes may have occurred at different times at our study sites than at the reference location, resulting in hyperlocal effects $[25,26,40]$.

Hyperlocality may also have affected the consistency of the lowest forest cover chronohorizon in Maryland. In our study, we applied a date of $1840 \pm 20$ for the lowest amount of forest cover, which is associated with peak Ambrosia [36]; however, this date was inconsistent with our NP-predicted age range of 1890-1910 at the depth where we observed this chronohorizon. In another study of Maryland pollen, the first peak of Ambrosia was found to correspond to peak lumber production between 1880 and 1920 [108]. This date is consistent with our NP-predicted date. Our date may be related to differences in the sampling locations because different parts of the Chesapeake Bay were deforested at different times [25].

In Connecticut, a large decline in chestnut pollen abundance occurs at $10 \mathrm{~cm}$ (Appendix $C$ ). Based on typical regional interpretations, this decline would be given a date of $1920 \pm 10$ CE $[44,45]$, due to the appearance of chestnut blight in New York City in 1904 and subsequent spread throughout the northeastern U.S. within 50 years [109]; however, 
this date is inconsistent with our other chronometers. In Bridgeport and New Haven, Connecticut, proximal to our site, Japanese chestnut trees were a popular ornamental on estates, and their pollen, which is very similar to that of American chestnut, may have obscured the decline in native chestnut due to blight [110-112]. During the 1960s, the ornamental chestnut trees were cut down during suburbanization $[113,114]$. Therefore, it is possible that the hyperlocal signal associated with ornamental chestnuts and their removal obscured the chestnut blight signal, dating chestnut decline at $10 \mathrm{~cm}$ in Connecticut as approximately 1960 , which is consistent with ${ }^{137} \mathrm{Cs}$ peak, gasoline-related $\mathrm{Pb}$ minimum, $\mathrm{Pb}$ peak, and Hg peak (Table 1).

Pollen signals can also be misinterpreted due to the effects of sediment mixing and bioturbation. Salt marsh and mangrove environments are subject to mixing and bioturbation, which can cause smearing of signals used to construct chronologies $[93,94]$. In the case of bioturbation, plants or animals mix sediments through their growth, burrowing, or searching for food, resulting in signal peaks being smeared upward [94,95]. This is particularly true in mangrove environments, which are significantly impacted by the activities of root growth and crabs [115]. Salt marshes and mangrove environments are also subject to reworking due to tidal activity and storms $[43,88,95]$. For example, there is visual evidence of tidal and storm reworked sediments within the salt marsh stratigraphy of Connecticut from [53]. Sediment mixing may be responsible for the difficulties in selecting chronohorizons associated with initial land clearance and start of the forestry industry. The abundance of Ambrosia is high at the base of the Connecticut core, which is unexpected due to the paleobotanical history of the area, but may be due to mixing in the core $[44,45]$. Finally, mixing of the pollen signal may occur from the erosion of older pollen from one site and redeposition in another, causing an older chronohorizon to appear in a younger section of core than expected [116].

Pollen chronohorizons may be inconsistent with other chronometers due to misinterpretation in identifying pollen signals. Quantitative chronohorizons are based on specific numerical cutoffs [36], such as the first or last appearances of Casuarina or Castanea $[44,45,65,66]$. Therefore, quantitative chronohorizons should be more readily identifiable than qualitative chronohorizons that are based on unspecified increases or decreases in pollen relative abundance. For a qualitative increase, the percent abundance of the pollen species in question often varies before the increase, making choosing the correct depth more difficult (Appendix C) [74,75]. Additionally, there may be multiple interpretations for a given pollen chronohorizon. For example, the qualitative chronohorizon associated with initial land clearance in New Jersey could be interpreted at either $87.5 \mathrm{~cm}$ or $62.5 \mathrm{~cm}$. We interpret the highest peak in Ambrosia at $87.5 \mathrm{~cm}$ as being associated with initial land clearance [36], whereas the pollen signals at $62.5 \mathrm{~cm}$ of increasing Ambrosia pollen, a sustained decrease in Quercus pollen, and the appearance of Plantago pollen are more consistent with the near-complete deforestation associated with lowest forest cover $[36,37,76,78]$. While both interpretations could be made, our interpretation is consistent with the other chronometers as the NP age range associated with $87.5 \mathrm{~cm}$ (1570 to $1670 \mathrm{CE})$ matches the reference date for initial land clearance in New Jersey of $1710 \pm 50$ years while the NP age range associated with $62.5 \mathrm{~cm}$ (1825 to 1870) does not.

A further issue that impacts both qualitative and quantitative chronohorizons is related to selecting the observed depth at which a pollen chronohorizon occurs-the event leading to the observation may have occurred between sampling depths. Depending on the sedimentation rate, a different sampling interval may impact the consistency of the pollen chronohorizons $[96,97]$. Sampling frequency can also affect the depth to which a chronohorizon is assigned $[117,118]$. Since pollen chronohorizons are assigned to depths where pollen is counted, a more frequent sampling interval will result in a more precise assignment of depth to a chronohorizon.

Finally, the other age markers may be based on erroneous dates, while the pollen date is accurate. Erroneous dating of other age markers could occur if a pollution marker or ${ }^{137} \mathrm{Cs}$ peak was mobilized by groundwater $[98-100,119]$. For example, ${ }^{137} \mathrm{Cs}$ bonds well with 
clay-sized sediment, but adheres less to organic particles, and therefore may be relatively mobile in organic salt marshes [99,120], particularly those high in humic acids, which keep ${ }^{137} \mathrm{Cs}$ in its dissolved form [121-123]. However, in the published studies (Table 1), 20th century pollution markers and ${ }^{137} \mathrm{Cs}$ peaks were used to reconstruct historical sealevel variability. The reconstructions were validated by instrumental tide gauge data, suggesting that these markers were in situ. Radiocarbon dates may also be erroneous through incorporation of either older carbon during sediment accumulation or younger carbon after deposition [101]. Contamination by younger carbon occurs as the result of root penetration or downward movement of humic acids [101,124]. However, all of our radiocarbon samples were prepared with careful screening procedures in an attempt to remove these contaminants.

\subsection{Application of Pollen Chronohorizons to Improve the Age-Depth Model}

Bchron's Bayesian probability model, like all Bayesian models, has the property that increasing the data quantity (and quality) by incorporating pollen chronohorizons reduces the uncertainty in the resulting model $[90,125]$. Inclusion of a pollen chronohorizon in agreement with other age markers improves the confidence in the model $[90,126]$ and allows the model to choose the most probable and perhaps accurate path $[90,126]$. For example, in North Carolina, the pollen chronohorizon associated with initial land clearance was consistent with the other age markers and was, therefore, able to help Bchron identify a different and more precise path by 20 years between the deepest pollution age marker and the shallowest radiocarbon date (Figure 6, Table 4).

Pollen chronohorizons also influence the precision of the age-depth models. The width of the $50 \%$ UI increased in six of the 24 models, decreased in seven models, and in 11 models had little or no change in precision (Table 4). Increases in precision ranged from five to 41 years. Several large increases ( $>10$ years) in precision were evident with the addition of the following pollen chronohorizons: initial land clearance in North Carolina, the beginning of the forestry industry in southern Florida, the appearance of Casuarina in southern Florida, and all age markers combined in southern Florida (Figure 5). In each of these models, the pollen chronohorizons are located in a temporally restricted portion (the portion with few age markers) of the core between pollution markers and radiocarbon dates or near poorly constrained radiocarbon dates. The radiocarbon dates commonly have $2 \sigma$ age ranges between $\sim 30$ to $>300$ years (Tables 1 and 2 ). In this temporally restricted region, pollen chronohorizons are particularly important as they provide dated depths in a portion of the core that is otherwise difficult to reconstruct $[6,38-40,127]$. In the age-depth model from North Carolina, for example, the inclusion of the initial land clearance pollen chronohorizon between the youngest radiocarbon date and the oldest pollution age marker increased the precision by narrowing the $50 \%$ UI of the age-depth model by an average of 20 years (Figures 4 and 5).

Pollen chronohorizons increased the 50\% UI width (i.e., decreased precision) in six cases by 5 to 16 years (Figure 5, Table 4). Two of these models included at least one inconsistent chronometer (initial land clearance and combined age markers in New Jersey) (Table 4). We do not, however, advise discarding pollen chronohorizons that do not improve precision unless they can be quantitatively determined to be an outlier.

Additionally, pollen chronohorizons sometimes have conflicting results (i.e., consistent chronohorizons fail to improve model precision or inconsistent chronohorizons improve model precision). For example, the overlap between the peak deforestation chronohorizon uncertainty in Delaware and the NP age range for its corresponding depth is only six years, which may lead to it decreasing precision in the model (Table 3). In New York, the pollen chronohorizon associated with reforestation occurs around 1960 [73], a time where several other age markers are also present, such as dates associated with ${ }^{137} \mathrm{Cs}$ onset and peak in 1954 and 1963, respectively, and a minimum in gasoline-related Pb isotopes in 1965 (Figure 6) [30,82]. Because there is sufficient time control in this section of core even without pollen included, Bchron is already able to produce narrow $50 \%$ UIs, and the inclusion of 
pollen chronohorizons cannot greatly improve upon the already precise model. Finally, an inconsistent pollen chronohorizon may improve the precision of the age-depth model when it occurs in a data poor area, such as the Casuarina introduction chronohorizon in southern Florida, suggesting a change in sedimentation rate that was not accounted for due to the sparsity of chronometers when pollen was excluded (Figures 5 and 6).

\subsection{Improving Pollen Chronohorizons}

To further improve age-depth models, pollen chronohorizons could be developed or adapted. For example, a new pollen chronohorizon could be developed based on the increase in Iva pollen. At our Connecticut site, there is an increase in Iva pollen at $34 \mathrm{~cm}$ at which corresponds to an age of 1865 to 1879. A similar increase is seen in New Jersey at $36 \mathrm{~cm}$ to $37 \mathrm{~cm}$ (1900 to 1916) and New York at $16 \mathrm{~cm}$ to $17 \mathrm{~cm}$ (1939 to 1946). A possible explanation for the increase in Iva is ditching to drain salt marshes so that they could be farmed or as a method of mosquito control [63]. The ditching and draining decreased flooding and improved the marsh-upland edge habitat preferred by Iva [128]. Ditching of salt marshes began in the late 1800s through early 1900s in Connecticut [61,63], in 1907 in New Jersey [60,129], and in 1913 near New York City (Miller, 2001). Additional sources could be used to constrain the specific timing of historical increases in ditching and other land-use changes in tidal wetlands.

\section{Conclusions}

We have collected published and unpublished pollen and chronology data (e.g., radiocarbon, ${ }^{137} \mathrm{Cs}$, and pollution horizons) from coastal wetlands along the U.S. Atlantic Coast to determine if pollen chronohorizons are consistent with other chronometers and if including pollen chronohorizons improves the precision of age-depth models. We reviewed the vegetation histories and regional literature to identify eight unique pollen chronohorizons with a maximum of three chronohorizons per study region. The eight pollen chronohorizons were applied to 24 age-depth models for the eight study regions (17 models using individual chronohorizons and seven models with combined age markers).

We found that the ages assigned to 13 out of 17 applications of individual pollen chronohorizons were consistent when compared with dates derived by the NP Bchron chronology. In four applications, the pollen chronohorizons were inconsistent in Connecticut (Chestnut blight) and Maryland (lowest forest cover) due to hyperlocality of pollen chronohorizons, in Connecticut (land clearance) due to sediment mixing, and in New Jersey (land clearance) due to misinterpretation of the pollen signals, and/or incorrect pollution and radiocarbon dates. A possible solution to the inconsistency of pollen chronohorizons is to down-weigh in Bchron and other Bayesian age-depth models using outlier probabilities [130], which has been previously applied to erroneous radiocarbon dates $[131,132]$.

We also assessed if the pollen chronohorizons improved the precision of the age depth models by comparing the median WP and NP 50\% UIs. In seven out of the total of 24 models, inclusion of one or more pollen chronohorizons in the age-depth model improved the precision by up to 41 years. In six of 24 models, the WP model reduced the precision. Precision was most improved with the addition of pollen chronohorizons at sites with insufficient data, such as the land clearance pollen chronohorizon in North Carolina and the pollen chronohorizons observed in southern Florida, and where pollen chronohorizons were consistent with other age markers, such as the start of the forestry industry in Connecticut. Reductions in precision were often due to wide uncertainty ranges for pollen chronohorizons and inconsistency of pollen chronohorizons with other age markers, such as the initial land clearance chronohorizon in New Jersey. Overall, the inclusion of pollen chronohorizons in age-depth models pertaining to salt marsh and mangrove environments can be helpful in situations where other types of age markers are sparse or have large age uncertainties. Sedimentary environments which contain abundant pollen with a known vegetation history are excellent candidates for this approach, 
particularly if other dates are lacking, unavailable, or uncertain. Including one or more pollen chronohorizons in such cases improves the robustness of the age-depth model.

Author Contributions: M.A.C.: Conceptualization, Methodology, Software, Validation, Formal Analysis, Investigation, Writing-Original Draft, Writing-Review and Editing, Visualization, Project Administration. C.E.B.: Conceptualization, Methodology, Writing-Review and Editing. A.C.P.: Conceptualization, Methodology, Software, Validation, Writing-Review and Editing. T.A.S.: Investigation, Data Curation, Writing-Review and Editing, Visualization. N.S.K.: Investigation, Data Curation, Writing-Review and Editing. D.R.C.: Investigation, Writing-Review and Editing. A.G.-A.: Investigation, Data Curation, Writing - Review and Editing. J.C.: Investigation, Data Curation, Writing-Review and Editing. J.S.W.: Investigation, Data Curation, Writing-Review and Editing. J.P.D.: Investigation, Data Curation, Methodology, Writing—Review and Editing. T.R.H.: Methodology, Software, Writing-Review and Editing, Visualization. B.P.H.: Project Administration, Supervision, Funding Acquisition, Conceptualization, Writing-Review and Editing. All authors have read and agreed to the published version of the manuscript.

Funding: MC was funded by the National Science Foundation EAR 1624551. NSK, TS, and BPH were funded by the Ministry of Education Academic Research Fund MOE2018-T2-1-030 and MOE2019T3-1-004, the National Research Foundation Singapore, and the Singapore Ministry of Education, under the Research Centres of Excellence initiative. This article is a contribution to International Geoscience Program (IGCP) Project 639, "Sea Level Change from Minutes to Millennia". This work is Earth Observatory of Singapore contribution 349. AP wishes to acknowledge the funding Science Foundation Ireland Career Development Award (17/CDA/4695); an investigator award (16/IA/4520); a Marine Research Programme funded by the Irish Government, co-financed by the European Regional Development Fund (Grant-Aid Agreement No. PBA/CC/18/01); European Union's Horizon 2020 research and innovation programme under grant agreement No 818144; and SFI Research Centre awards 16/RC/3872 and 12/RC/2289_P2.

Institutional Review Board Statement: Not applicable.

Informed Consent Statement: Not applicable.

Data Availability Statement: The data presented in this study are available in this paper. Data from published studies are available in the referenced papers.

Acknowledgments: MC wishes to acknowledge Andy Kemp for his support and advice throughout the process of studying pollen chronohorizons and Debra Willard for U.S. Geological Survey review of the manuscript. Any use of trade, product, or firm names is for descriptive purposes only and does not imply endorsement by the U.S. Government.

Conflicts of Interest: The authors declare no conflict of interest. 


\section{Appendix A}

Table A1. Chronological data for published sites. UMV refers to lead (Pb) pollution originating from the Upper Mississippi Valley. YBP = years before present.

\begin{tabular}{|c|c|c|c|c|c|c|c|c|c|c|c|c|}
\hline & \multicolumn{4}{|c|}{ Connecticut [48] } & \multicolumn{4}{|c|}{ New York [51] } & \multicolumn{4}{|c|}{ New Jersey [52] } \\
\hline & Lab Code & Depth (cm) & $\begin{array}{c}\text { Age }\left({ }^{14} \mathrm{C}\right. \\
\text { Years) }\end{array}$ & $\begin{array}{l}\text { Calibrated Age } \\
\text { Range (YBP) }\end{array}$ & Lab Code & Depth (cm) & $\begin{array}{c}\text { Age }\left({ }^{14} \mathrm{C}\right. \\
\text { Years) }\end{array}$ & $\begin{array}{c}\text { Calibrated Age } \\
\text { Range (YBP) }\end{array}$ & Lab Code & Depth (cm) & $\begin{array}{c}\text { Age }\left({ }^{14} \mathrm{C}\right. \\
\text { Years) }\end{array}$ & $\begin{array}{l}\text { Calibrated Age } \\
\text { Range (YBP) }\end{array}$ \\
\hline \multirow{13}{*}{ 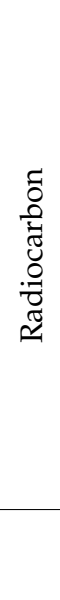 } & OS-88674 & $56 \pm 2$ & $175 \pm 30$ & 3-284 & OS-102551 & $60 \pm 1$ & $165 \pm 25$ & $6-280$ & $14 \mathrm{C} 10$ & $76 \pm 1$ & $120 \pm 30$ & $18-265$ \\
\hline & OS-86561 & $66 \pm 2$ & $345 \pm 25$ & $318-480$ & OS-108259 & $70 \pm 1$ & $380 \pm 30$ & $325-500$ & $14 \mathrm{C} 12$ & $82 \pm 1$ & $230 \pm 25$ & $1-305$ \\
\hline & OS-86562 & $78 \pm 2$ & $550 \pm 30$ & $523-633$ & OS-108260 & $81 \pm 1$ & $285 \pm 25$ & $294-432$ & $14 \mathrm{C} 4$ & $86 \pm 1$ & $250 \pm 40$ & $4-431$ \\
\hline & OS-89141 & $90 \pm 2$ & $835 \pm 25$ & $696-786$ & OS-102552 & $95 \pm 1$ & $770 \pm 30$ & $672-733$ & $14 \mathrm{C} 11$ & $94 \pm 1$ & $285 \pm 30$ & $289-447$ \\
\hline & OS-86567 & $111 \pm 2$ & $1080 \pm 30$ & $936-1053$ & OS-115123 & $105 \pm 1$ & $695 \pm 20$ & $574-676$ & $14 \mathrm{C} 8$ & $111 \pm 1$ & $400 \pm 25$ & $336-505$ \\
\hline & OS-86616 & $146 \pm 2$ & $1300 \pm 25$ & $1186-1284$ & OS-109016 & $123 \pm 1$ & $1420 \pm 30$ & $1294-1369$ & $14 C 5$ & $122 \pm 1$ & $520 \pm 40$ & $508-29$ \\
\hline & OS-89764 & $158 \pm 2$ & $1490 \pm 30$ & $1317-1480$ & OS-102598 & $137 \pm 1$ & $1180 \pm 35$ & $996-1213$ & $14 \mathrm{C} 2$ & $145 \pm 1$ & $865 \pm 25$ & $720-890$ \\
\hline & OS-89059 & $165 \pm 2$ & $1570 \pm 25$ & $1406-1525$ & OS-102553 & $155 \pm 1$ & $1560 \pm 25$ & $1396-1522$ & $14 \mathrm{C} 6$ & $160 \pm 1$ & $960 \pm 40$ & $785-936$ \\
\hline & OS-88962 & $184 \pm 2$ & $1790 \pm 25$ & $1629-1807$ & OS-102554 & $161 \pm 1$ & $1630 \pm 35$ & $1419-1605$ & $14 \mathrm{C} 3$ & $171 \pm 1$ & $1100 \pm 30$ & $946-1061$ \\
\hline & & & & & & & & & $14 \mathrm{C} 13$ & $180 \pm 1$ & $1120 \pm 25$ & 969-1069 \\
\hline & & & & & & & & & $14 \mathrm{C} 7$ & $194 \pm 1$ & $1190 \pm 35$ & $1008-1225$ \\
\hline & & & & & & & & & $14 \mathrm{C} 9$ & $208 \pm 1$ & $1350 \pm 30$ & $1193-1307$ \\
\hline & $\begin{array}{l}\text { Depth } \\
(\mathrm{cm})\end{array}$ & $\begin{array}{c}\text { Age } \\
\text { (year CE) }\end{array}$ & \multicolumn{2}{|c|}{ Age Marker } & Depth $(\mathrm{cm})$ & $\begin{array}{c}\text { Age } \\
\text { (year CE) }\end{array}$ & \multicolumn{2}{|c|}{ Age Marker } & $\begin{array}{l}\text { Depth } \\
(\mathrm{cm})\end{array}$ & $\begin{array}{c}\text { Age } \\
\text { (year CE) }\end{array}$ & \multicolumn{2}{|c|}{ Age Marker } \\
\hline \multirow{15}{*}{ 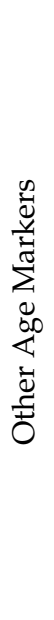 } & $3 \pm 4$ & $1970 \pm 5$ & \multicolumn{2}{|c|}{ Hg Peak } & $7 \pm 2.5$ & $1963 \pm 1$ & \multicolumn{2}{|c|}{${ }^{137}$ Cs Peak } & $21 \pm 4$ & $1980 \pm 5$ & \multicolumn{2}{|c|}{ Gas Pb Peak } \\
\hline & $4 \pm 4$ & $1963 \pm 1$ & \multicolumn{2}{|c|}{${ }^{137}$ Cs Peak } & $11 \pm 2$ & $1974 \pm 5$ & \multicolumn{2}{|c|}{ Pb Peak } & $21 \pm 4$ & $1974 \pm 5$ & \multicolumn{2}{|c|}{$\mathrm{Pb}$ Peak } \\
\hline & $9 \pm 6$ & $1974 \pm 5$ & \multicolumn{2}{|c|}{$\mathrm{Pb}$ Peak } & $11 \pm 2$ & $1970 \pm 5$ & \multicolumn{2}{|c|}{ V Peak } & $36.5 \pm 12$ & $1969 \pm 11$ & \multicolumn{2}{|c|}{ Ni Onset } \\
\hline & $13 \pm 6$ & $1965 \pm 5$ & \multicolumn{2}{|c|}{ Zn Peak } & $11 \pm 1.5$ & $1954 \pm 2$ & \multicolumn{2}{|c|}{${ }^{137}$ Cs Onset } & $29 \pm 4$ & $1965 \pm 5$ & \multicolumn{2}{|c|}{ Gas $\mathrm{Pb}$ Min } \\
\hline & $19 \pm 6$ & $1935 \pm 6$ & \multicolumn{2}{|c|}{ Great Depression $\mathrm{Pb}$ Min } & $13 \pm 6$ & $1970 \pm 5$ & \multicolumn{2}{|c|}{ Cu Peak } & $17 \pm 2$ & $1963 \pm 1$ & \multicolumn{2}{|c|}{${ }^{137}$ Cs Peak } \\
\hline & $21 \pm 4$ & $1905 \pm 5$ & & g Peak & $17 \pm 6$ & $1965 \pm 5$ & & $\mathrm{~Pb}$ Min & $24.5 \pm 4$ & $1963 \pm 7$ & & d Peak \\
\hline & $22 \pm 6$ & $1880 \pm 20$ & & $V$ Decline & $21 \pm 4$ & $1937 \pm 5$ & & k Incin. & $28.5 \pm 4$ & $1956 \pm 13$ & & n Peak \\
\hline & $31 \pm 6$ & $1900 \pm 5$ & & Onset & $27 \pm 2$ & $1933 \pm 6$ & Great De & ression $\mathrm{Pb}$ Min & $29 \pm 4$ & $1948 \pm 15$ & & b Min \\
\hline & $33 \pm 6$ & $1925 \pm 5$ & & b Peak & $33 \pm 2$ & $1900 \pm 5$ & & Onset & $33 \pm 4$ & $1925 \pm 5$ & & b Peak \\
\hline & $33 \pm 4$ & $1865 \pm 10$ & & g Onset & $39 \pm 2$ & $1925 \pm 5$ & & Peak & $32.5 \pm 4$ & $1900 \pm 10$ & & Onset \\
\hline & $37 \pm 6$ & $1858 \pm 5$ & & YV Peak & $41 \pm 8$ & $1857 \pm 5$ & & IV Peak & $44.5 \pm 8$ & $1890 \pm 10$ & & Onset \\
\hline & $43 \pm 6$ & $1875 \pm 5$ & & Onset & $51 \pm 2$ & $1827 \pm 5$ & & V Onset & $45 \pm 4$ & $1880 \pm 5$ & UN & $V$ Decline \\
\hline & $43 \pm 6$ & $1827 \pm 5$ & & IV onset & & & & & $49 \pm 4$ & $1875 \pm 5$ & & Onset \\
\hline & & & & & & & & & $59 \pm 4$ & $1857 \pm 5$ & & 1V Peak \\
\hline & & & & & & & & & $69 \pm 4$ & $1827 \pm 5$ & & IV Onset \\
\hline
\end{tabular}


Table A1. Cont.

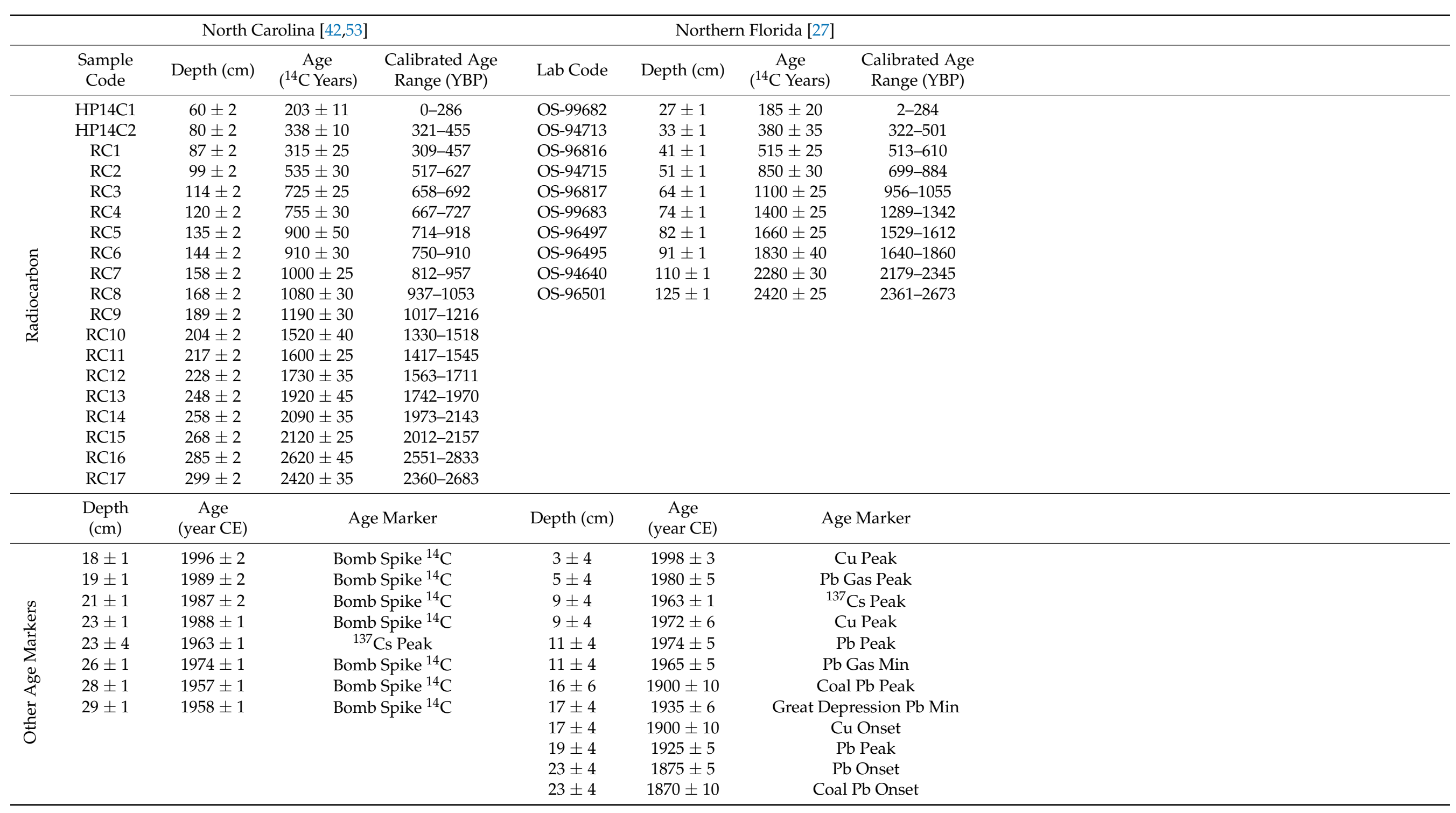




\section{Appendix B}

\section{B.1. Southern Delaware}

The southern Delaware site is located in the Great Marsh, northwest of Lewes, DE $(38.78,-75.18)$. It is $20 \mathrm{~km}^{2}$ in area and is separated from the Delaware Bay by a sand barrier [133]. The tidal range is $1.4 \mathrm{~m}$ and tides are semi-diurnal (NOAA tide gauge, Station ID: 8557380$)$. The tidal range has been influenced by anthropogenic activities, such as ditching and deforestation since the 1930s [37,134]. The southern Delaware site has a vertical zonation of plants: the low marsh is dominated by Spartina alterniflora tall form; the high marsh by Spartina alterniflora short form, Spartina patens, and Distichlis spicata; and the transition to freshwater upland by Phragmites australis, Iva frutescens, and Baccharis halimifolia. The climate at this site is warm temperate, and it has hot, humid summers [135]. The monthly average highs and lows range between 45 and $-2{ }^{\circ} \mathrm{C}$ in January to 30 and $20{ }^{\circ} \mathrm{C}$ in July [136]. There is an average of $117 \mathrm{~cm}$ of precipitation at the southern Delaware site per year [136].

\section{B.2. Maryland}

The Maryland site is located in the Kirkpatrick salt marsh $(38.87,-76.55)$. This salt marsh is located at the Smithsonian Environmental Research Center (SERC), near Mayo, Maryland and is on the northern Chesapeake Bay. It encompasses approximately 70 hectares of brackish marsh. The Maryland site is microtidal, with wind-influenced tides of less than $0.3 \mathrm{~m}$. This site is dominated by Phragmites australis, Spartina alterniflora, and Distichlis spicata, with patches of Spartina patens. The wetland cored for the Maryland site is used for a variety of long-term environmental experiments by SERC [137]. The climate at the Maryland site is warm temperate [135]. The average monthly high and low temperatures at this site range between 7 and $-2{ }^{\circ} \mathrm{C}$ in January to 32 and $22^{\circ} \mathrm{C}$ in July [136]. At the Maryland site, $120 \mathrm{~cm}$ of precipitation per year on average [136].

\section{B.3. Southern Florida}

The southern Florida site is located on Swan Key in the Florida Keys (25.34, - 80.25). This site is a microtidal mangrove swamp with a great diurnal range of $0.44 \mathrm{~m}$ (NOAA tide gauge, Station ID: 8723467). The mangrove swamp is dominated by three species of mangroves: Rhizophora mangle, Avicennia germinans, and Laguncularia racemosa. The climate at the southern Florida site is classified as a tropical savannah climate, with wet and dry periods throughout the year [59]. The average high is $28^{\circ} \mathrm{C}$ and the average low is $21^{\circ} \mathrm{C}$ with $145 \mathrm{~cm}$ of precipitation per year [136]. 


\section{Appendix C}
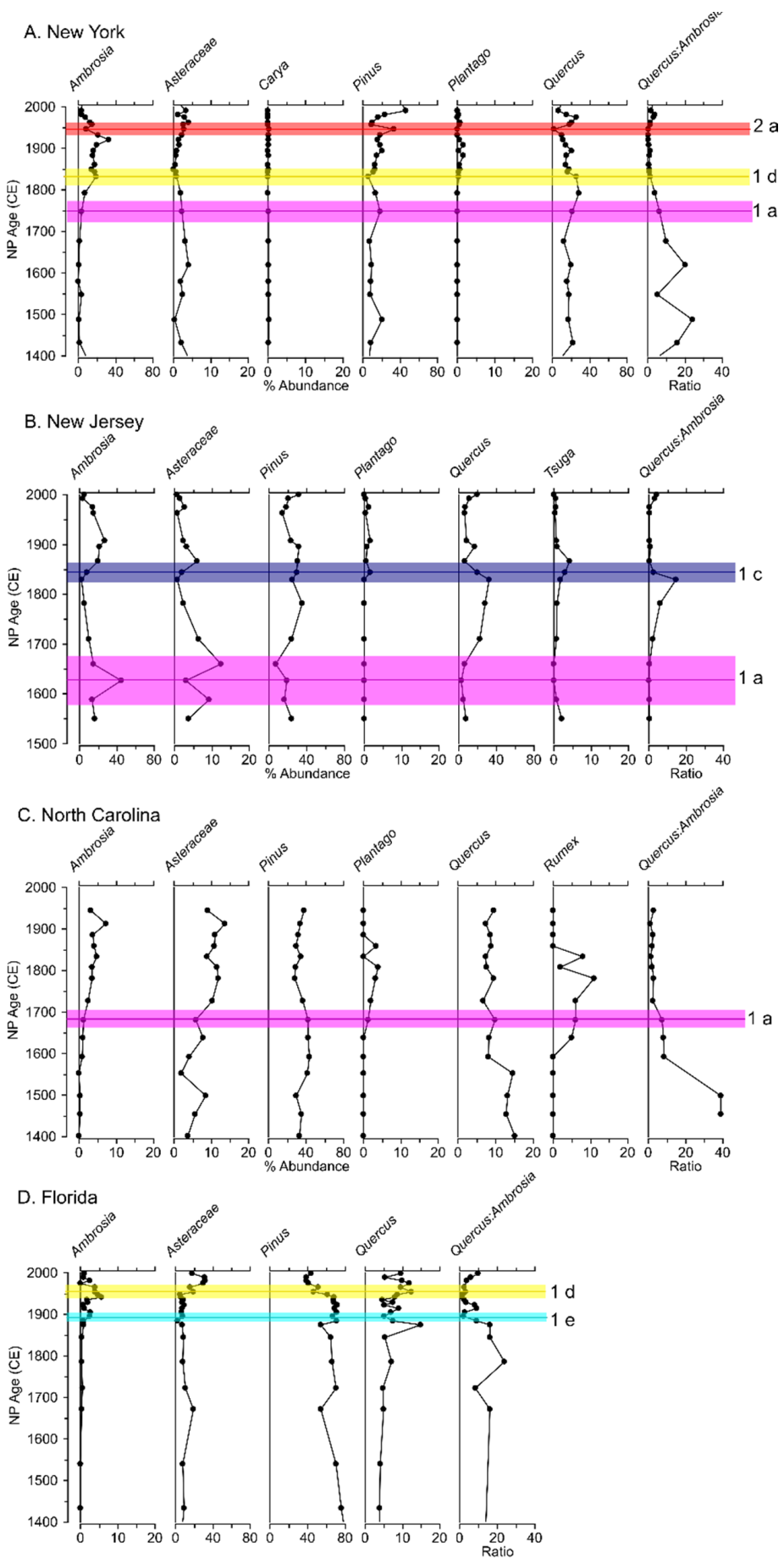

Figure A1. Pollen stratigraphic diagrams for published data plotted against the NP Bchron predicted ages to compare the age plus uncertainty of the pollen chronohorizons with the ages derived from other age markers at the depth where the pollen chronohorizon occurred for New York (A), New Jersey (B), North Carolina (C), and Northern Florida (D). Colored lines indicate the pollen chronohorizons; colored shading indicates the uncertainty associated with each pollen chronohorizon. The colors refer to Figure 3. The chronohorizons are as follows: (2a) reforestation; (1d) beginning of the forestry industry; (1a) initial land clearance; (1c) lowest amount of forest cover; and (1e) railroad expansion (Table 3). 


\section{Appendix B}
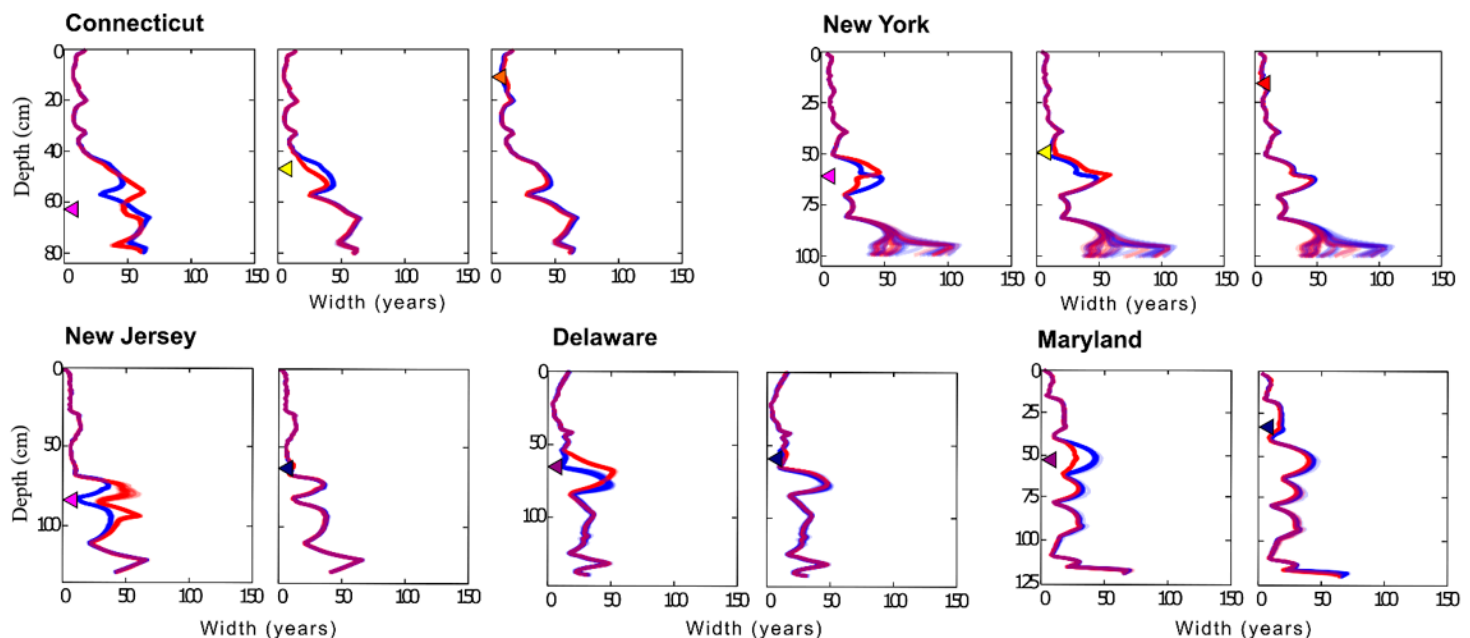

\section{Maryland}
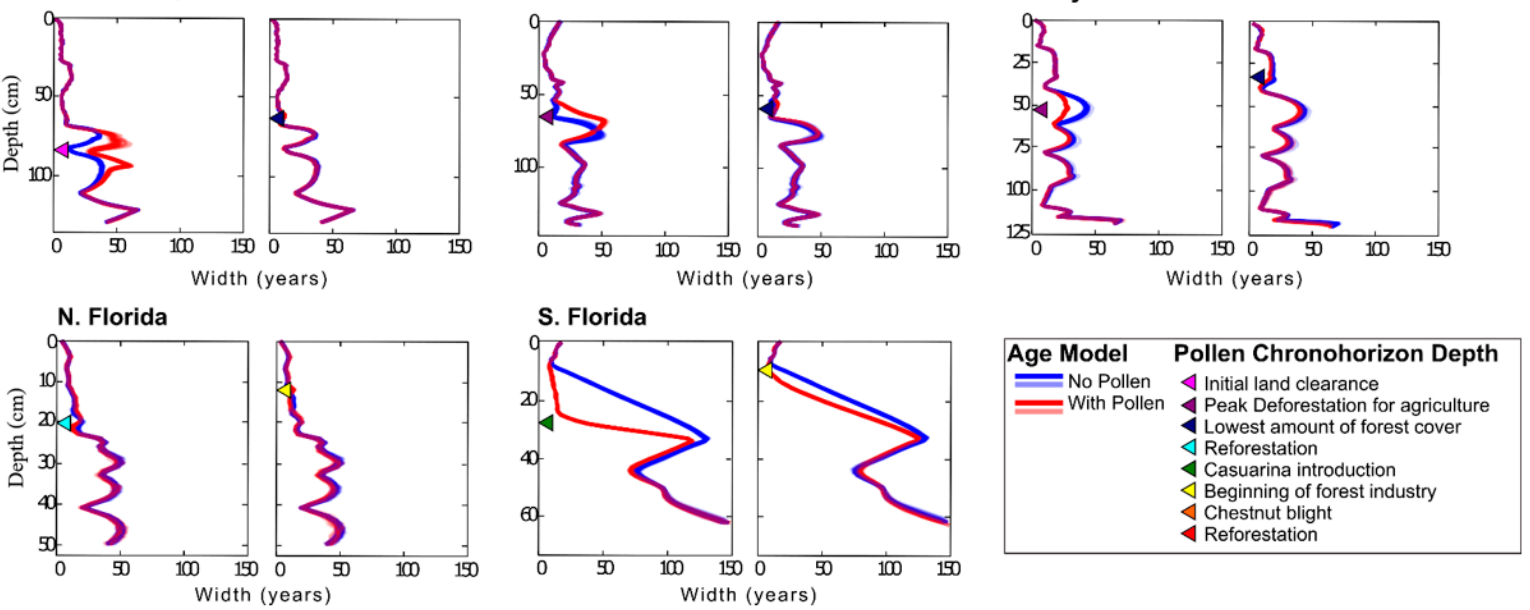

Figure A2. Comparison of the difference in width of the 50\% UI between the WP (red) and the NP (blue) models for each of the individual chronohorizon models over the interval from $1500 \mathrm{CE}$ through the present. The red and blue lines are plotted transparently so that lighter areas represent widths that are predicted less frequently by Bchron, while darker areas represent widths that are predicted more frequently.

\section{References}

1. Crowley, T.J. Causes of Climate Change Over the Past 1000 Years. Science 2000, 289, 270-277. [CrossRef] [PubMed]

2. Mann, M.E.; Zhang, Z.; Rutherford, S.; Bradley, R.S.; Hughes, M.K.; Shindell, D.; Ammann, C.; Faluvegi, G.; Ni, F. Global Signatures and Dynamical Origins of the Little Ice Age and Medieval Climate Anomaly. Science 2009, 326, 1256-1260. [CrossRef] [PubMed]

3. Reynolds, D.J.; Scourse, J.D.; Halloran, P.R.; Nederbragt, A.J.; Wanamaker, A.D.; Butler, P.G.; Richardson, C.A.; Heinemeier, J.; Eiriksson, J.; Knudsen, K.L.; et al. Annually resolved North Atlantic marine climate over the last millennium. Nat. Commun. 2016, 7, 13502. [CrossRef] [PubMed]

4. Jones, M.C.; Bernhardt, C.E.; Krauss, K.W.; Noe, G.B. The impact of late Holocene land use change, climate variability, and sea level rise on carbon storage in tidal freshwater wetlands on the southeastern United States coastal plain. J. Geophys. Res. Biogeosci. 2017, 122, 3126-3141. [CrossRef]

5. Stager, J.C.; Wiltse, B.; Hubeny, J.B.; Yankowsky, E.; Nardelli, D.; Primack, R. Climate variability and cultural eutrophication at Walden Pond (Massachusetts, USA) during the last 1800 years. PLoS ONE 2018, 13, e0191755. [CrossRef]

6. Gorham, E.; Brush, G.S.; Graumlich, L.J.; Rosenzweig, M.L.; Johnson, A.H. The value of paleoecology as an aid to monitoring ecosystems and landscapes, chiefly with reference to North America. Environ. Rev. 2001, 9, 99-126. [CrossRef]

7. Schurer, A.P.; Mann, M.E.; Hawkins, E.; Tett, S.F.B.; Hegerl, G.C. Importance of the pre-industrial baseline for likelihood of exceeding Paris goals. Nat. Clim. Chang. 2017, 7, 563-568. [CrossRef]

8. Reiners, P.W.; Carlson, R.W.; Renne, P.R.; Cooper, K.M.; Granger, D.E.; McLean, N.M.; Schoene, B. Geochronology and Thermochronology; John Wiley \& Sons: Hoboken, NJ, USA, 2017.

9. Noller, J.; Sowers, J.M.; Coleman, S.M.; Pierce, K. Introduction to Quaternary Geochronology; American Geophysical Union: Washington, DC, USA, 2000.

10. Libby, W.F.; Anderson, E.C.; Arnold, J.R. Age Determination by Radiocarbon Content: World-Wide Assay of Natural Radiocarbon. Science 1949, 109, 227-228. [CrossRef]

11. Stuiver, M.; Reimer, P.J.; Bard, E.; Beck, J.W.; Burr, G.S.; Hughen, K.A.; Kromer, B.; McCormac, G.; Van Der Plicht, J.; Spurk, M. INTCAL98 radiocarbon age calibration, 24,000-0 cal BP. Radiocarbon 1998, 40, 1041-1083. [CrossRef] 
12. Reimer, P.J.; Bard, E.; Bayliss, A.; Beck, J.W.; Blackwell, P.G.; Bronk Ramsey, C.; Buck, C.E.; Cheng, H.; Edwards, R.L.; Friedrich, M.; et al. INTCAL13 and MARINE13 Radiocarbon Age Calibration Curves 0-50,000 Years Cal BP. Radiocarbon 2013, 55, $1869-1887$. [CrossRef]

13. Hua, Q. Radiocarbon: A chronological tool for the recent past. Quat. Geol. 2009, 4, 378-390. [CrossRef]

14. Stuiver, M. Radiocarbon timescale tested against magnetic and other dating methods. Nature 1978, 273, 271-274. [CrossRef]

15. Keeling, C.D. The Suess effect: ${ }^{13}$ Carbon $-{ }^{14}$ Carbon interrelations. Environ. Int. 1979, 2, 229-230. [CrossRef]

16. Tans, P.P.; Mook, W.G. Design, construction, and calibration of a high accuracy Carbon-14 counting system. Radiocarbon 1978, 21, 22-40. [CrossRef]

17. Reimer, P.J.; Reimer, R.W. Radiocarbon Dating: Calibration. In Encyclopedia of Quaternary Science; Elais, S.A., Ed.; Elsevier: Oxford, UK, 2007; pp. 2941-2949.

18. Hua, Q.; Barbetti, M.; Rakowski, A.Z. Atmospheric radiocarbon for the period 1950-2010. Radiocarbon 2013, 55, 2059-2072. [CrossRef]

19. Goldberg, E.D. Geochronology with ${ }^{210} \mathrm{~Pb}$ Radioactive Dating; International Atomic Energy Agency: Vienna, Austria, 1963; Volume 121, p. 130.

20. Appleby, P.G.; Oldfield, F. Application of 210-Pb to sedimentation studies. In Uranium-Series Disequilibrium: Applications to Earth, Marine, E Environmental Studies; Ivanovich, M., Harmon, R.S., Eds.; Oxford University Press: Oxford, UK, $1992 ;$ pp. 731-778.

21. Robbins, J.A. Geochemical and geophysical applications of radioactive lead. In Biogeochemistry of Lead in the Environment; Elsevier Scientific: Oxford, UK, 1978; pp. 285-293.

22. Cutshall, N.H.; Larsen, I.L.; Olsen, C.R. Direct analysis of ${ }^{210} \mathrm{~Pb}$ in sediment samples: Self-absorption corrections. Nucl. Instrum. Methods Phys. Res. 1983, 206, 309-312. [CrossRef]

23. He, Q.; Walling, D.E. Rates of Overbank Sedimentation on the Floodplains of British Lowland Rivers Documented Using Fallout ${ }^{137}$ Cs. Geogr. Ann. Ser. A Phys. Geogr. 1996, 78, 223-234. [CrossRef]

24. Walling, D.E.; He, Q. Models for converting 137-Cs measurements to estimates of soil redistribution rates on cultivated and uncultivated soils (including software for model implementation). In Report to IAEA; University of Exeter: Exeter, UK, 1997.

25. Brush, G.S. Rates and patterns of estuarine sediment accumulation. Limnol. Oceanogr. 1989, 34, 1235-1246. [CrossRef]

26. Cooper, S.R.; McGlothlin, S.K.; Madritch, M.; Jones, D.L. Paleoecological Evidence of Human Impacts on the Neuse and Pamlico Estuaries of North Carolina, USA. Estuaries 2004, 27, 617-633. [CrossRef]

27. Kemp, A.C.; Bernhardt, C.E.; Horton, B.P.; Kopp, R.E.; Vane, C.H.; Pertier, W.R.; Hawkes, A.D.; Donnelly, J.P.; Parnell, A.C.; Cahill, N. Late Holocene sea- and land-level change on the U.S. southeastern Atlantic Coast. Mar. Geol. 2014, 357, 90-100. [CrossRef]

28. MacKenzie, A.B.; Hardie, S.M.L.; Farmer, J.G.; Eades, L.J.; Pulford, I.D. Analytical and sampling constraints in ${ }^{210} \mathrm{~Pb}$ dating. Sci. Total Environ. 2011, 409, 1298-1304. [CrossRef] [PubMed]

29. Barsanti, M.; Garcia-Tenorio, R.; Schirone, A.; Rozmaric, M.; Ruiz-Fernández, A.C.; Sanchez-Cabeza, J.A.; Delbono, I.; Conte, F.; Godoy, J.D.O.; Heijnis, H.; et al. Challenges and limitations of the ${ }^{210} \mathrm{~Pb}$ sediment dating method: Results from an IAEA modelling interlaboratory comparison exercise. Quat. Geochronol. 2020, 59, 101093. [CrossRef]

30. Varekamp, J.C.; Kreulen, B.; Buchholtz ten Brink, M.R.; Mecrey, E.L. Mercury contamination chronologies from Connecticut wetlands and Long Island Sound sediments. Environ. Geol. 2003, 4, 468-482. [CrossRef]

31. Schottler, S.P.; Engstrom, D.R. A chronological assessment of Lake Okeechobee (Florida) sediments using multiple dating markers. J. Paleolimnol. 2006, 36, 19-36. [CrossRef]

32. Metcalfe, S.; Derwent, D. Atmospheric Pollution and Environmental Change; Routledge: Abingdon, UK, 2014.

33. Katz, A.; Kaplan, I.R. Heavy metal behavior in coastal sediments of southern California: A critical review and synthesis. Mar. Chem. 1981, 10, 261-299. [CrossRef]

34. Sanchez-Cabeza, J.A.; Druffel, E.R. Environmental records of anthropogenic impacts on coastal ecosystems: An introduction. Mar. Pollut. Bull. 2009, 59, 87-90. [CrossRef]

35. Kemp, A.C.; Sommerfield, C.S.; Vane, C.H.; Horton, B.P.; Chenery, S.R.; Anisfeld, S.; Nikitina, D. Use of lead isotopes for developing chronologies in recent salt-marsh sediments. Quat. Geochronol. 2012, 12, 40-49. [CrossRef]

36. Brush, G.S. Patterns of recent sediment accumulation in Chesapeake Bay (Virginia-Maryland, USA) tributaries. Chem. Geol. 1984, 44, 227-242. [CrossRef]

37. Matlack, G.R. Four Centuries of Forest Clearance and Regeneration in the Hinterland of a Large City. J. Biogeogr. 1997, 24, 281-295. [CrossRef]

38. Roe, H.M.; Van de Plassche, O. Modern pollen distribution in a Connecticut saltmarsh: Implications for studies of sea-level change. Quat. Sci. Rev. 2005, 24, 2030-2049. [CrossRef]

39. Hilgartner, W.B.; Brush, G.S. Prehistoric habitat stability and post-settlement habitat change in a Chesapeake Bay freshwater tidal wetland, USA. Holocene 2006, 16, 479-494. [CrossRef]

40. Bernhardt, C.E.; Willard, D.A. Pollen and spores of terrestrial plants. In Handbook of Sea-Level Research; Shennan, I., Long, A.J., Horton, B.P., Eds.; Wiley: Hoboken, NJ, USA, 2015; pp. 218-232.

41. Pederson, D.C.; Peteet, D.M.; Kurdyla, D.; Guilderson, T. Medieval Warming, Little Ice Age, and European impact on the environment during the last millennium in the lower Hudson Valley, New York, USA. Quat. Res. 2005, 63, 238-249. [CrossRef]

42. Kemp, A.C.; Kegel, J.J.; Culver, S.J.; Barber, D.C.; Mallinson, D.J.; Leorri, E.; Bernhardt, C.E.; Bernhardt, C.E.; Cahill, N.; Riggs, S.R.; et al. Extended late Holocene relative sea-level histories for North Carolina, USA. Quat. Sci. Rev. 2017, 160, 13-30. [CrossRef] 
43. Donnelly, J.P.; Roll, S.; Wengren, M.; Butler, J.; Lederer, R.; Webb III, T. Sedimentary evidence of intense hurricane strikes from New Jersey. Geology 2001, 29, 615-618. [CrossRef]

44. Brugam, R.B. Pollen indicators of land-use change in southern Connecticut. Quat. Res. 1978, 9, 349-362. [CrossRef]

45. Clark, J.S.; Patterson, W.A. Pollen, Pb-210, and opaque spherules; an integrated approach to dating and sedimentation in the intertidal environment. J. Sediment. Res. 1984, 54, 1251-1265.

46. Mudie, P.J.; Byrne, R. Pollen evidence for historic sedimentation rates in California salt-marshes. Estuar. Coast. Mar. Sci. 1980, 10, 305-316. [CrossRef]

47. Bernabo, J.C.; Webb, T. Changing patterns in the Holocene pollen record of northeastern North America: A mapped summary. Quat. Res. 1977, 8, 64-96. [CrossRef]

48. Barbier, E.D.; Hacker, S.D.; Kennedy, C.; Koch, E.W.; Stier, A.C.; Silliman, B.R. The value of estuarine and coastal ecosystem services. Ecol. Monogr. 2011, 81, 169-193. [CrossRef]

49. Gedan, K.B.; Silliman, B.R.; Bertness, M.D. Centuries of Human-Driven Change in Salt-Marsh Ecosystems. Annu. Rev. Mar. Sci. 2009, 1, 117-144. [CrossRef]

50. Craft, C.; Clough, J.; Ehman, J.; Joye, S.; Park, R.; Pennings, S.; Guo, H.; Machmuller, M. Forecasting the Effects of Accelerated Sea-Level Rise on Tidal Marsh Ecosystem Services. Front. Ecol. Environ. 2008, 7, 73-78. [CrossRef]

51. Deegan, L.A.; Johnson, D.S.; Warren, R.S.; Peterson, B.J.; Fleeger, J.W.; Fagherazzi, S.; Wollheim, W.M. Coastal eutrophication as a driver of salt marsh loss. Nature 2012, 490, 388-392. [CrossRef] [PubMed]

52. Horton, B.P.; Shennan, I.; Bradley, S.L.; Cahill, N.; Kirwan, M.; Kopp, R.E.; Shaw, T.A. Predicting marsh vulnerability to sea-level rise using Holocene relative sea-level data. Nat. Commun. 2018, 9, 1-7. [CrossRef] [PubMed]

53. Kemp, A.C.; Hawkes, A.D.; Donnelly, J.P.; Vane, C.H.; Horton, B.P.; Hill, T.D.; Anisfeld, S.C.; Parnell, A.C.; Cahill, N. Relative sea-level change in Connecticut (USA) during the last 2200 yrs. Earth Planet. Sci. Lett. 2015, 428, 217-229. [CrossRef]

54. Parnell, A.C. Bchron: Radiocarbon Dating, Age-Depth Modelling, Relative Sea Level Rate Estimation, and Non-Parametric Phase Modelling. Available online: https:/ /rdrr.io/cran/Bchron/ (accessed on 15 June 2018).

55. USDA Forest Service. USFS Forest Inventory and Analysis (FIA) Program; Geospatial Technology and Applications Center (GTAC) National Forest Type Dataset. Available online: https:/ / data.fs.usda.gov/geodata/rastergateway/forest_type/ (accessed on 12 February 2019).

56. Kemp, A.C.; Hill, T.D.; Vane, C.H.; Cahill, N.; Orton, P.M.; Talke, S.A.; Parnell, A.C.; Sanborn, K.; Hartig, E.L. Relative sea-level trends in New York City during the past 1500 years. Holocene 2017, 27, 1169-1186. [CrossRef]

57. Kemp, A.C.; Horton, B.P.; Vane, C.H.; Bernhardt, C.E.; Corbett, D.R.; Engelhart, S.E.; Anisfeld, S.C.; Parnell, A.C.; Cahill, N. Sea-level change during the last 2500 years in New Jersey, USA. Quat. Sci. Rev. 2013, 81, 90-104. [CrossRef]

58. Kemp, A.C.; Buzas, M.A.; Horton, B.P.; Culver, S.J. Influence of patchiness on modern salt-marsh foraminifera used in sea-level studies (North Carolina, USA). J. Foraminifer. Res. 2011, 41, 114-123. [CrossRef]

59. Peel, M.C.; Finlayson, B.L.; McMahon, T.A. Updated world map of the Köppen-Geiger climate classification. Hydrol. Earth Syst. Sci. 2007, 11, 1633-1644. [CrossRef]

60. Burger, J.; Shisler, J. Nest site selection and competitive interactions of herring and laughing gulls in New Jersey. Auk 1978, 95, 252-266.

61. Rozsa, R. Human impacts on tidal wetlands: History and regulations. Vol. Bulletin No. 34. In Tidal Marshes of Long Island Sound: Ecology, History and Restoration; Dreyer, G.D., Niering, W.A., Eds.; The Connecticut Arboretum Press: New London, CT, USA, 1995; pp. 42-50.

62. Miller, J.R. The Control of Mosquito-Borne Diseases in New York City. J. Urban Health Bull. N. Y. Acad. Med. 2001, 78, 359-366. [CrossRef]

63. Bromberg, K.D.; Bertness, M.D. Reconstructing New England Salt-marsh Losses Using Historical Maps. Estuaries 2005, 28, 823-832. [CrossRef]

64. McAndrews, J.H. Human disturbance of North American forests and grasslands: The fossil pollen record. In Handbook of Vegetation Science; Huntley, B., Webb, T., III, Eds.; Kluwer Academic Publishing: Dordrecht, The Netherlands, 1988 ; Volume 7.

65. Alexander, T.R.; Crook, A.G. Recent vegetational changes in southern Florida. Environments of Southern Florida: Present and Past. Memoir 1974, 2, 61-72.

66. Morton, J.F. The Australian pine or Beefwood (Casuarina equisetifolia), and invasive "weed" tree in Florida. Proc. Fla. Hortic. Soc. 1980, 93, 87-95.

67. De Vleescheuwer, F.; Chambers, F.M.; Swindles, G.T. Coring and sub-sampling of peatlands for paleoenvironmental research. Mires Peat 2010, 7, 1-10.

68. Faegri, K.; J Iverson, J. Textbook on Pollen Analysis, 4th ed.; Hafner: New York, NY, USA, 1989.

69. Foster, D.R.; Zebryk, T.; Schoonmaker, P.; Lezberg, A. Post-settlement history of human land-use and vegetation dynamics of a Tsuga canadensis (hemlock) woodlot in central New England. J. Ecol. 1992, 80, 773-786. [CrossRef]

70. Nevel, R.L., Jr.; Stochia, E.L.; Wahl, T. New York Timber Industries—A Periodic Assessment of Timber Output, Resource Bulletin NE-73; United States Department of Agriculture, Forest Service, Northeast Forest Experimental Station: Upper Darby, PA, USA, 1982.

71. Burrows, E.G.; Wallace, M. Gotham: A History of New York City to 1898; Oxford University Press: Oxford, UK, 2000.

72. Russell, E.W.B. Vegetational Change in Northern New Jersey from Precolonization to the Present: A Palynological Interpretation. Bull. Torrey Bot. Club 1980, 107, 432-446. [CrossRef] 
73. Fain, J.J.; Volk, T.A.; Fahey, T.J. Fifty Years of Change in an Upland Forest in South-Central New York: General Patterns. Bull. Torrey Bot. Club 1994, 121, 130-139. [CrossRef]

74. Wacker, P.O. Land and People: A Cultural Geography of Preindustrial New Jersey Origins and Settlement Patterns; Rutgers University Press: Newark, NJ, USA, 1975; Volume 1.

75. Wacker, P.O.; Clemens, P.G.E. Land Use in Early New Jersey; A Historical Geography; Rutgers University Press: Newark, NJ, USA, 1994.

76. Bones, J.T. The Timber Industries of New Jersey and Delaware, Resource Bulletin NE-28; United States Department of Agriculture, Forest Service, Northeastern Forest Experimental Station: Upper Darby, PA, USA, 1973.

77. Jones, C.F. A landscape of energy abundance: Anthracite. Coal Canals and the Roots of American Fossil Fuel Dependence, 1820-1860. Environ. Hist. 2010, 15, 449-484. [CrossRef]

78. Johannes, J.H. Yesterday's Reflections: Nassau County, Florida: A Pictorial History. Nassau Co. Florida: T.O. Richardson. 1976. Available online: http://www.wnhsfl.org/nassau-county-history.html (accessed on 12 February 2019).

79. Wingard, G.L.; Hudley, J.W.; Holmes, C.W.; Willard, D.A.; Marot, M. Synthesis of Age Data and Chronology for Florida Bay and Biscayne Bay Cores Collected for Ecosystem History of South Florida's Estuaries Project; No. 2007-1203; US Geological Survey: Reston, VA, USA, 2007.

80. Marshall, F.E.; Bernhardt, C.E.; Wingard, G.L. Estimating Late 19th Century Hydrology in the Greater Everglades Ecosystem: An Integration of Paleoecologic Data and Models. Front. Environ. Sci. 2020, 8, 3. [CrossRef]

81. Niu, M.; Heaton, T.J.; Blackwell, P.G.; Buck, C.E. The Bayesian approach to radiocarbon calibration curve estimation: The IntCal13, Marine13, and SHCal13 methodologies. Radiocarbon 2013, 55, 1905-1922. [CrossRef]

82. UNSCEAR. Sources and Effects of Ionizing Radiation; Report to the General Assembly; United Nations: New York, NY, USA, 2000.

83. He, Q.; Walling, D.E. The distribution of fallout $137-\mathrm{Cs}$ and $210-\mathrm{Pb}$ in undisturbed and cultivated soils. Appl. Radioact. Isot. 1997, 48, 677-690. [CrossRef]

84. Marcantonio, F.; Zimmerman, A.; Xu, Y.; Canuel, E. A Pb isotope record of mid-Atlantic U.S. atmospheric Pb emissions in Chesapeake Bay sediments. Mar. Chem. 2002, 77, 123-132. [CrossRef]

85. Lima, A.L.; Bergquist, B.A.; Boyle, E.A.; Reuer, M.K.; Dudas, F.O.; Reddy, C.M.; Eglinton, T.I. High-resolution historical records from Pettaquamscutt River basin sediments: 2. Pb isotopes reveal a potential new stratigraphic marker. Geochim. Cosmochim. Acta 2005, 69, 1813-1824. [CrossRef]

86. Hurst, R.W. Lead isotopes as age-sensitive genetic markers in hydrocarbons. 3. Leaded gasoline, 1923-1990 (ALAS model). Environ. Geosci. 2002, 9, 43-50. [CrossRef]

87. Bricker-Urso, S.; Nixon, S.W.; Cochran, J.K.; Hirschberg, D.J.; Hunt, C. 1989. Accretion rates and sediment accumulation in Rhode Island salt-marshes. Estuaries 1989, 12, 300-317. [CrossRef]

88. Donnelly, J.P.; Bryant, S.S.; Butler, J.; Dowling, J.; Fan, L.; Hausmann, N.; Newby, P.; Shuman, B.; Stern, J.; Westover, K.; et al. A 700-year sedimentary record of intense hurricane landfalls in southern New England. Geol. Soc. Am. Bull. 2001, 113, 714-727. [CrossRef]

89. Haslett, J.; Parnell, A. A simple monotone process with application to radiocarbon-dated depth chronologies. J. R. Stat. Soc. 2008, 3, 399-418. [CrossRef]

90. Parnell, A.C.; Haslett, J.; Allen, J.R.M.; Buck, C.E.; Huntley, B. A flexible approach to assessing synchroneity of past events using Bayesian reconstructions of sedimentation history. Quat. Sci. Rev. 2008, 27, 1872-1885. [CrossRef]

91. Scott, E.M.; Cook, G.; Naysmith, P. The fifth international radiocarbon intercomparison (VIRI): An assessment of laboratory performance in stage 3. Radiocarbon 2010, 53, 859-865. [CrossRef]

92. David, H.A.; Nagaraja, H.N. Order Statistics; Wiley Series in Probability and Statistics: New York, NY, USA, 2003.

93. Sharma, P.; Gardner, L.R.; Moore, W.S.; Bollinger, M.S. Sedimentation and bioturbation in a salt-marsh as revealed by ${ }^{210} \mathrm{~Pb},{ }^{137} \mathrm{Cs}$, and ${ }^{7}$ Be studies. Limnol. Oceanogr. 1987, 32, 313-326. [CrossRef]

94. Vernberg, F.J. Salt-marsh processes: A review. Environ. Toxicol. Chem. 1993, 12, 2167-2195. [CrossRef]

95. Leorri, E.; Martin, R.E.; Horton, B.P. Field experiments on bioturbation in salt-marshes (Bombay Hook National Wildlife Refuge, Smyrna, DE, USA: Implications for sea-level studies. J. Quat. Sci. 2009, 24, 139-149. [CrossRef]

96. Jacobson, G.L.; Bradshaw, R.H.W. The Selection of Sites for Paleovegetational Studies. Quat. Res. 1981, 16, 80-96. [CrossRef]

97. MacDonald, G.M. Fossil pollen analysis and the reconstruction of plant invasions. In Advances in Ecological Research; Academic Press: Cambridge, MA, USA, 1993; Volume 24, pp. 67-110.

98. Dubinski, B.J.; Simpson, R.L.; Good, R.E. The retention of heavy metals in sewage sludge applied to a freshwater tidal wetland. Estuaries 1986, 9, 102-111. [CrossRef]

99. Bryant, C.L.; Farmer, J.G.; MacKenzie, A.B.; Baily-Watt, A.E.; Kirika, A. Distribution and behaviour of radiocaesium in Scottish freshwater loch sediments. Environ. Geochem. Health 1993, 15, 153-161. [CrossRef] [PubMed]

100. Amos, K.J.; Croke, J.C.; Timmers, H.; Owens, P.N.; Thompson, C. The application of caesium-137 measurements to investigate floodplain deposition in a large semi-arid catchment in Queensland, Australia: A low-fallout environment. Earth Surf. Process. Landf. 2009, 34, 515-529. [CrossRef]

101. Kemp, A.C.; Nelson, A.R.; Horton, B.P. Radiocarbon Dating of Plant Macrofossils from Tidal-Marsh Sediment. In Methods in Geomorphology, in Treatise on Geomorphology; Switzer, A.D., Kennedy, D.M., Eds.; Academic Press: San Diego, CA, USA, 2013; Volume 14, pp. 370-388. 
102. Marshall, W. Chronohorizons: Indirect and unique event dating methods for sea-level reconstructions. In Handbook for Sea-Level Research; Shennan, I., Long, A.J., Horton, B.P., Eds.; Wiley: Hoboken, NJ, USA, 2015; pp. 373-385.

103. Schueler, S.; Schlünzen, K.H. Modeling of oak pollen dispersal on the landscape level with a mesoscale atmospheric model. Environ. Model. Assess. 2006, 11, 179-194. [CrossRef]

104. Trondman, A.K.; Gaillard, M.J.; Mazier, F.; Sugita, S.; Fyfe, R.; Nielsen, A.B.; Twiddle, C.; Barratt, P.; Birks, H.J.B.; Bjune, A.E.; et al. Pollen-based quantitative reconstructions of Holocene regional vegetation cover (plant-functional types and land-cover types) in Europe suitable for climate modelling. Glob. Chang. Biol. 2015, 21, 676-697. [CrossRef]

105. Traverse, A. Paleopalynology, 2nd ed.; Springer Science \& Business Media: Berlin/Heidelberg, Germany, 2007 ; Volume 28.

106. McLauchlan, K.K.; Barnes, C.S.; Craine, J.M. Interannual variability of pollen productivity and transport in mid-North America from 1997 to 2009. Aerobiologia 2011, 27, 181-189. [CrossRef]

107. Zink, K.; Vogel, H.; Vogel, B.; Magyar, D.; Kottmeier, C. Modeling the dispersion of Ambrosia artemisiifolia L. pollen with the model system COSMO-ART. Int. J. Biometeorol. 2012, 56, 669-680. [CrossRef]

108. Willard, D.A.; Cronin, T.M.; Verardo, S. Late-Holocene climate and ecosystem history from Chesapeake Bay sediment cores, USA. Holocene 2003, 13, 201-214. [CrossRef]

109. Anderson, T.W. The chestnut pollen decline as a time horizon in lake sediments in eastern North America. Can. J. Earth Sci. 1974, 11, 678-685. [CrossRef]

110. Anagnostakis, S.L.; Hillman, B. Evolution of the Chestnut Tree and Its Blight. Arnoldia 1992, 52, 2-10.

111. Anagnostakis, S.L. Chestnuts and the Introduction of Chestnut Blight. The Agricultural Connecticut Experimental Station. Available online: https: / / www.ct.gov/CAES/cwp/view.asp?a=2815\&q=376754 (accessed on 10 October 2018).

112. Anagnostakis, S.L. American Chestnuts in the 21st Century. Arnoldia 2009, 66, 23-31.

113. Nicolaides, B.; Wiese, A. Suburbanization in the United States after 1945; Oxford Research Encyclopedias: American History; Oxford University Press: Oxford, UK, 2017; Available online: http:/ / americanhistory.oxfordre.com/view/10.1093/acrefore/9780199329 175.001.0001/acrefore-9780199329175-e-64 (accessed on 10 October 2018).

114. Anagnostakis, S.L.; Department of Plant Pathology and Ecology, The Connecticut Agricultural Experiment Station, New Haven, CT, USA. Personal communication, 2018.

115. Ellison, J.C. Modeling of oak pollen dispersal on the landscape level with a mesoscale atmospheric model. Palaeogeogr. Palaeoclimatol. Palaeoecol. 1989, 74, 327-341. [CrossRef]

116. Neulieb, T.; Levac, E.; Southon, J.; Lewis, M.; Pendea, I.F.; Chmura, G.L. Potential pitfalls of pollen dating. Radiocarbon 2013, 55, 1142-1155. [CrossRef]

117. Turner, J.; Peglar, S.M. Temporally-precise studies of vegetation history. In Vegetation History; Springer: Dordrecht, The Netherlands, 1988; pp. 753-777.

118. Bennington, J.B.; Rutherford, S.D. Precision and reliability in paleocommunity comparisons based on cluster-confidence intervals; how to get more statistical bang for your sampling buck. Palaios 1999, 14, 506-515. [CrossRef]

119. Hovenac, C. Reconstructing the Erosional History of 19th-Century Earthen Fortifications along the Coastline of the Chesapeake Bay, Maryland, USA. Master's Thesis, University of Delaware, Newark, DE, USA, 2015.

120. Torgensen, T.; Longmore, M. ${ }^{137}$ Cs diffusion in the highly organic sediment of -Hidden Lake, Fraser Island, Queensland. Mar. Freshw. Res. 1984, 35, 537-548. [CrossRef]

121. Farmer, J.G. The perturbation of historical pollution records in aquatic sediments. Environ. Geochem. Health 1991, 13, 76-83. [CrossRef]

122. Abril, J.M. Constraints on the use of ${ }^{137}$ Cs as a time-marker to support CRS and SIT chronologies. Environ. Pollut. 2004, 129, 31-37. [CrossRef]

123. Campbell, C.A.; Paul, E.A.; Rennie, D.A.; McCallum, R.J. Mid-infrared spectroscopy as a method of characterizing changes in soil organic matter. Soil Sci. Soc. Am. Proc. 1967, 77, 1591-1600.

124. Thompson, J.; Dyer, F.M.; Croudace, I.W. Records of radionuclide deposition in two salt marshes in the United Kingdom with contrasting redox and accumulation conditions. Geochim. Cosmochim. Acta 2002, 66, 1011-1023. [CrossRef]

125. Blaauw, M.; Christen, J.A.; Bennett, K.D.; Reimer, P.J. Double the dates and go for Bayes-Impacts of model choice, dating density and quality on chronologies. Quat. Sci. Rev. 2018, 188, 58-66. [CrossRef]

126. Telford, R.J.; Heegaard, E.; Birks, H.J.B. All age-depth models are wrong: But how badly? Quat. Sci. Rev. 2004, 23, 1-5. [CrossRef]

127. Brush, G.S.; Martin, E.A.; Defries, R.S.; Rice, C.A. Comparisons of ${ }^{210} \mathrm{~Pb}$ and Pollen Methods for Determining Rates of Estuarine Sediment Accumulation. Quat. Res. 1982, 18, 196-217. [CrossRef]

128. Bertness, M.D.; Wikler, K.; Chatkupt, T. Flood tolerance and the distribution of Iva frutescens across New England salt-marshes. Oecologia 1992, 91, 171-178. [CrossRef]

129. Smith, J.B. The New Jersey Salt-Marsh and Its Improvement; New Jersey Agricultural Environmental Station: New Brunswick, NJ, USA, 1907.

130. Hamilton, W.D.; Kenney, J. Multiple Bayesian modelling approaches to a suite of radiocarbon dates from ovens excavated at Ysgol yr Hendre, Caernarfon, North Wales. Quat. Geol. 2014, 25, 72-82. [CrossRef]

131. Bronk Ramsey, C. Bayesian analysis of radiocarbon dates. Radiocarbon 2009, 51, 337-360. [CrossRef]

132. Blaauw, M.; Christen, J.A. Radiocarbon Peat Chronologies and Environmental Change. J. R. Stat. Soc. Ser. C (Appl. Stat.) 2005, 54, 805-816. [CrossRef] 
133. Stedman, S.M. Sedimentology and Stratigraphy of the Great Marsh, Lewes, Delaware. Ph.D. Thesis, University of Delaware, Newark, DE, USA, 1990.

134. Wolfe, R.J. Effects of open marsh water management on selected tidal marsh resources: A review. J. Am. Mosq. Control Assoc. 1996, 12, 701-712.

135. Kottek, M.; Grieser, J.; Beck, C.; Rudolf, B.; Rubel, F. World map of the Köppen-Geiger climate classification updated. Meteorol. Z. 2006, 15, 259-263. [CrossRef]

136. Weather Service. US Climate Data. Available online: https:/ /www.usclimatedata.com/ (accessed on 15 June 2018 ).

137. Smithsonian Environmental Research Center. Available online: https:/ / serc.si.edu/ (accessed on 18 November 2019). 